\title{
With Criminal Intent? Forgers at Work in Roman London
}

\author{
By JENNY HALL
}

\begin{abstract}
Over 800 clay coin moulds, excavated from 85 London Wall in 1988, had been used for casting copies of silver denarii and copper-alloy dupondii and asses which dated from Trajan to Trebonianus Gallus. The discovery of the moulds in the ditch of Londinium's defensive wall led initially to thoughts that this was the concealment of incriminating evidence, but it is now recognised that counterfeiting coins was rife and perhaps even uncontrollable. The wide variety of moulds made it a complicated task to identify the numbers and types of coins used to make the moulds. This article describes the types of moulds found, examines how the moulds were produced, and discusses the prevalence of coin moulds at differing periods and on differing sites in Roman Britain and on the Continent.
\end{abstract}

Keywords: clay moulds; Roman coins; cast coins; counterfeiting; forgeries; minting

\section{INTRODUCTION}

$\mathrm{F}$ ull details of the excavation at 85 London Wall have remained unpublished for 25 years leading to a long delay in reporting the discovery of the coin moulds in full. A brief report of the find appeared in a paper by George Boon, ${ }^{1}$ and more recently an interim summary appeared in a discussion of the moulds from Saint-Mard in Belgium and a review of moulds from the North-Western provinces. ${ }^{2}$ A full catalogue of the moulds and the moulds themselves are lodged with the London Archaeological Archive and Research Centre of the Museum of London.

The City of London's square mile was determined more than 1,800 years ago when the Romans built a landward city wall, stretching from the site of the Tower of London around to Blackfriars. About $3 \mathrm{~km}$ in length, it was built in c. A.D. 200 with a $\mathrm{V}$-shaped defensive ditch $(5 \mathrm{~m}$ wide and $1.5 \mathrm{~m}$ deep) dug some $4 \mathrm{~m}$ away from the outside of the wall. In the troublesome years of the later third and fourth centuries, the city wall was strengthened by the addition of semi-circular towers, or bastions, on the eastern section of the wall between Tower Hill and Moorgate. A large group of over 800 clay moulds for the production of counterfeit coins was excavated from the ditch to the

Boon 1988.

2 Lallemand 1994. 
north of the city wall, and its location led to the suggestion that it was a forger's cache, hidden to escape detection. The coins used to make the moulds dated from Trajan in the early second century to Trebonianus Gallus in the mid-third century and were a mix of denarii, dupondii and asses.

\section{THE EXCAVATION AT 85 LONDON WALL}

The site (BLM87; TQ 32970 81510), on the corner of London Wall and Blomfield Street, was excavated by Museum of London Archaeology in early 1988 (FIG. 1). Not only did it reveal a

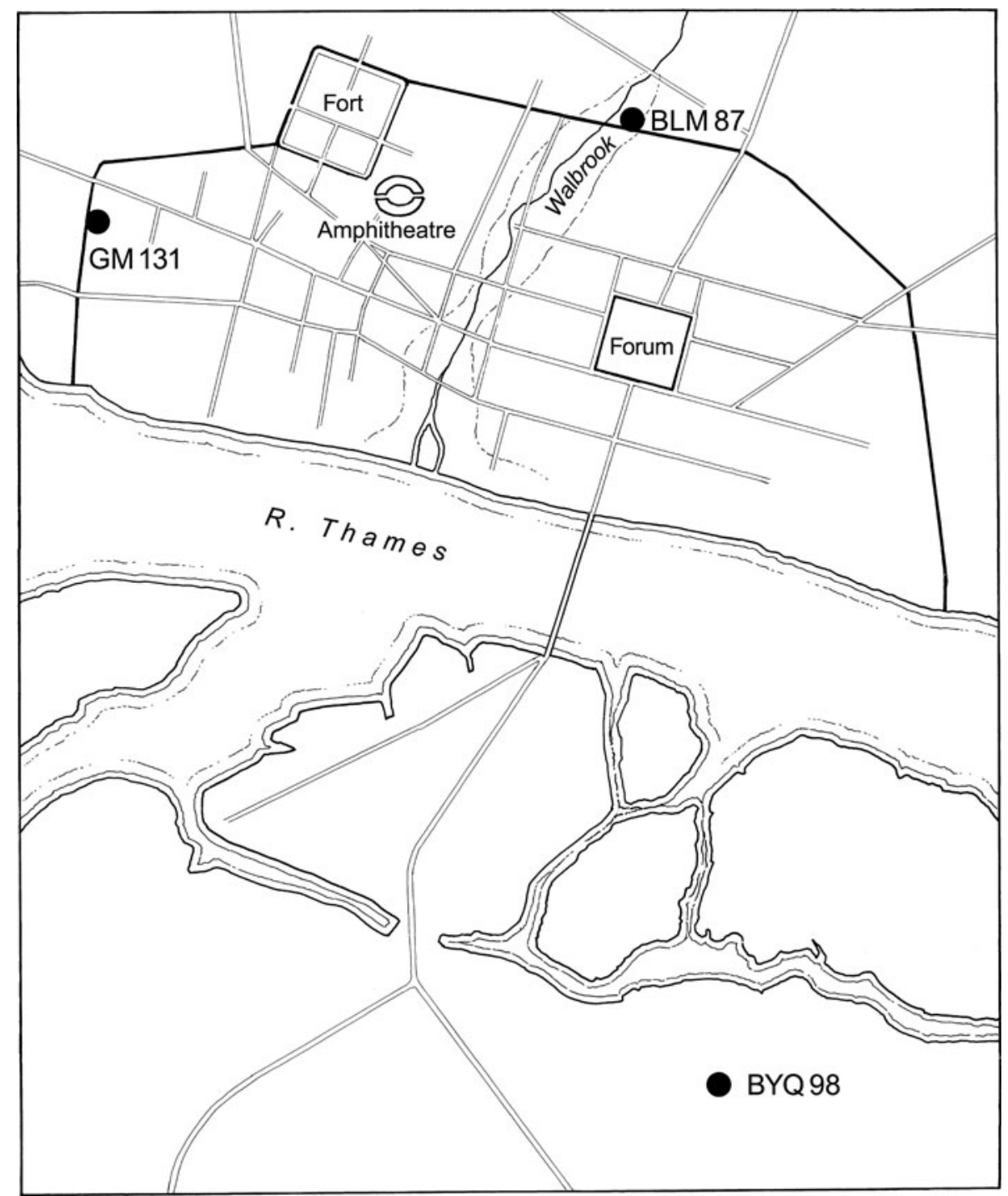

FIG. 1. London sites where clay coin moulds have been found: BLM87 — city ditch, 85 London Wall; GM131 — internal turret, Central Criminal Court, Newgate Street; BYQ98 - agricultural ditch, Bermondsey Square, Southwark. 
section of city wall - adding to the length of the wall that survives at the adjacent All Hallows church, London Wall - but it also revealed the possible site of a hitherto unknown bastion built on the outside of the wall, ${ }^{3}$ west of the bastion that lies under the vestry of the church itself. This northern part of the Roman city was crossed by several streams which joined to form the Walbrook, the main stream through the city. The area was, therefore, subject to flooding especially following the construction of the city wall.

Two trenches were excavated, providing a north-to-south section through the city ditch and a west-to-east section exposing an upstanding stretch of the city wall, which rises to some $7 \mathrm{~m}$ in height. The main Roman feature of the site was a drainage system that fed into parallel ditches that led into the large city ditch. The ditch, when excavated at that point, contained human bone, leather shoes and nine whole funerary pots, five of which were unbroken and held offerings of chickens and coins. They were thought to be from burials washed out from a cemetery further to the north. ${ }^{4}$ In addition, a large number of clay moulds, for producing counterfeit Roman coins, were found scattered through several contexts in the ditch. Extreme fluctuations in the water level of the ditch led to the accumulation of various sediments and the dispersion of the coin moulds is thought to have been caused by water flowing through the ditch during the Roman period.

The contents of the ditch showed that building material and human bone lay at the bottom with coin moulds lying on the sloping side of the ditch, while the upper layer was a mix of moulds and building material. The moulds were found in a number of contexts (mainly 219, 220 and 253) which, at the time, were described variously as: alluviated ditch sediment of dark grey/brown silty clay (219) in which the coin moulds were mainly concentrated towards the east; a mid-brown organic ditch silting (220); and a grey/brown silty clay (253).

The moulds, reported here, were not the only ones to be revealed at the site. Some were seen in section at the edge of the site, but could not be retrieved for safety reasons. A collection of 34 moulds and an associated clay fragment, acquired from a workman by the Museum of London in 2001, was found during construction works after the archaeologists had vacated the site and these moulds have been included in the catalogue. ${ }^{5}$ This collection has also been included in Table 1, as well as being counted in the reverse types (Appendix 1). Two further moulds were later acquired by a private collector. These were aes moulds, one of Trebonianus Gallus with a reverse of Concordia Augg and the other of Herennia Etruscilla with a blank reverse. The Ulster Museum, Belfast, also reported similar examples from the site brought in for identification by another workman, but no record survives for these. It has also been suggested that more moulds were seen on another nearby site (Great Winchester Street/Blomfield Street). The total published here, therefore, will never be the final or absolute total.

\section{INFLATION AND COUNTERFEITING COINS IN THE THIRD CENTURY}

Officially-minted Roman coins were struck using engraved coin dies, top and bottom, which stamped blank metal discs to produce double-sided coins. Counterfeits were produced in various ways, the easiest being the casting of coins using clay or metal moulds. Forging coins was something that was rife throughout the Roman period. According to a Republican law of 81 B.C., and updated by an Imperial law, it was a criminal act incurring the death penalty for tampering with gold and exile for silver. ${ }^{6}$ It has been calculated that by the mid-third century

David Sankey, pers. comm.

Schofield and Maloney 1998, 242-3.

MoL Acc. No.: 2009.62/1-35.

Boon 1988. 
A.D., in particular, a large number of silver coins in circulation were either plated or fake, although it is impossible to calculate just how many. A survey conducted by Philippa Walton, during post-graduate research using data from the Portable Antiquities Scheme, ${ }^{7}$ found that about one third of early third-century denarii were likely to be fake. Therefore, although forging was a criminal act, it was at times uncontrollable and such forgeries tended to occur when there were shortages of certain coins and high inflation.

During the second and third centuries A.D., the stock of available silver became insufficient to provide the number of coins needed. As a consequence, the silver coinage was debased by the addition of copper in varying and increasing amounts and the silver radiate was introduced initially in A.D. 214. This radiate is thought to have had twice the value of the denarius and ultimately replaced the denarius - which went out of production in c. A.D. 241 (the radiate having been re-introduced in A.D. 238); initially the radiate consisted of about 30 per cent silver. By c. A.D. 270, the radiate contained only a minute percentage of silver. As a consequence, large numbers of counterfeit denarii were being produced, often regarded as forgeries which in essence they were, but they were obviously filling a need as there were not enough coins in circulation.

Third-century copper-alloy coinage, although not as common as in the previous two centuries, still occurs regularly, but many sestertii in Britain are heavily-worn second-century specimens. During the early third century the civilian provinces in the Mediterranean still received their supply of copper-alloy coinage, especially of sestertii, but a mere trickle of newly-minted copper-alloy coinage was being supplied to the frontier military provinces (Britain, northern Gaul and Germany). ${ }^{8}$ Dupondii and asses were especially rare in these areas. Therefore, although they were still being minted at Rome, such coins are not common as British finds. ${ }^{9}$ The relationship between silver and copper-alloy coinage in circulation in the early to mid-third century, for example, is amply demonstrated by the Portable Antiquities Scheme database, ${ }^{10}$ where the types of coinage lost in Roman Britain are divided into three periods: A.D. 193-222; 222-38, and 238-60. Denarii recorded from these three periods total 2,926, 816, and 36 respectively; radiates 40,12 , and 2,133 ; sestertii 142,101 , and 72 ; dupondii 16,13 , and 8 ; and asses 45,48 , and 73 . These figures clearly demonstrate the declining numbers of denarii to radiates as the denarius was phased out. The rise in the production of increasingly-debased denarii and then radiates was accompanied by a decline in the supply of bronze coinage to the province and this low level of supply continued. ${ }^{11}$ Walton's research showed that there was a high spike in the number of denarii lost in the earlier period and she suggested that this was the result of the military campaigns in Roman Britain and the need to pay the army. She showed also that dupondii and asses appeared regularly, but she suggested that they remained at consistently low levels owing both to inflation and the continued circulation of earlier coinage. ${ }^{12}$

British hoards also demonstrate the small percentages of dupondii and asses in the third century. The Nevill Holt hoard from Leicestershire, ${ }^{13}$ for example, had 253 sestertii, dupondii and asses in a worn condition, spanning the emperors from Augustus to Postumus. It also included 16 lightweight cast copper-alloy coins (limesfalsa) - produced from worn copper-alloy asses of the first and second centuries - being used to fill the gap in supply. ${ }^{14}$ In the A.D. 270 s, when

Walton 2012.
Abdy 2007.
Abdy 2003.
R. Bland, pers. comm.
Walton 2012, 43 .
Walton 2012, $44-6$ and fig. 22.
Abdy forthcoming.
For lightweights, see Boon 1988, 124-5 and fig. 3. 
all the copper-alloy coinage was finally melted down, the metal was perhaps recycled in part to produce the debased radiates. Analysis has shown that some 'silver' radiates of that period contained zinc as well as copper (zinc was an element of the orichalcum from which sestertii were made). ${ }^{15}$

Before the discovery of the Cunetio hoard from near Marlborough, Wilts., very few cast coins had been noticed in hoards. Research on the hoard containing 54,951 coins, gathered during a period of political and monetary crisis in the Roman Empire (A.D. 260-75) showed that, of these, 2,085 radiates were struck forgeries and 63 were copies of radiates dating to the A.D. 270 s, cast from moulds impressed from original coins. ${ }^{16}$ The coating for these irregular radiates varied from silver or tin to a base white metal or they simply remained as copper alloy.

\section{UNOFFICIAL COIN PRODUCTION}

Turning to the question of forging and the production of coins. Official coins were produced using pre-cast coin blanks which were struck between engraved dies. No physical evidence for official coin production has been found from Roman Britain, but there are several instances of unofficial production. A copper-alloy die, for example, from Verulamium and engraved with the reverse of a denarius of Hadrian, ${ }^{17}$ is thought to have been part of a forger's equipment. ${ }^{18}$ A forger's obverse die for a denarius of Marcus Aurelius Caesar from Skirpenbeck, Yorks., ${ }^{19}$ and a reverse die for a denarius of Crispina from Humberside, ${ }^{20}$ both unpublished, show that the striking of fake denarii was not unusual. A find of a late third-century coin manufacturer's hoard from Fenny Stratford, Bucks., revealed two possible incomplete dies and the raw materials required for producing coins. The find consisted of three coarseware vessels containing copper-alloy blanks, cast as globules of copper alloy (gunmetal with very low percentages of zinc and silver); pellets, cut from cast rods of alloy (leaded high-tin bronze); and a pair of possible iron dies which no longer had the copper-alloy engraved dies attached. Bob Zeepvat suggested that such a find was not indicative of a criminal act, with the evidence being buried to avoid discovery and punishment, but that it should be regarded as the local unofficial production of coins that filled a need owing to lack of coin supply. ${ }^{21}$

False denarii were either cast in an alloy totally lacking in silver - for example, a high-tin bronze that made it look like silver - or cast in a base metal and then plated. Such casts were produced either in small numbers in two-piece slab moulds or in quantity in clay moulds stacked in columns. The moulds were made as either single- or double-sided moulds and were produced by impressing struck coins into the clay. Double-sided examples bore an obverse impression of a coin on one side and a reverse on the other, though not necessarily from the same coin. Single-sided moulds bore a coin impression on one side only and could be either the obverse or reverse of a coin.

There is no shortage of examples of clay moulds from both Roman Britain and the Continent. Boon listed evidence for coin moulds in Roman Britain, dividing the evidence into known periods of counterfeiting. ${ }^{22}$ The information concerning the location of sites — with those dating to the particular period of the London moulds being highlighted - is presented in FIG. 2 (for details of the moulds and coin types used, see ONLINE TABLE 1). Some 26 sites in Britain have yielded

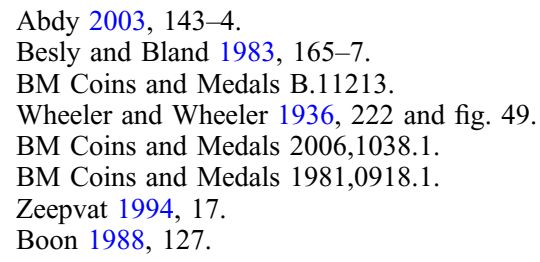




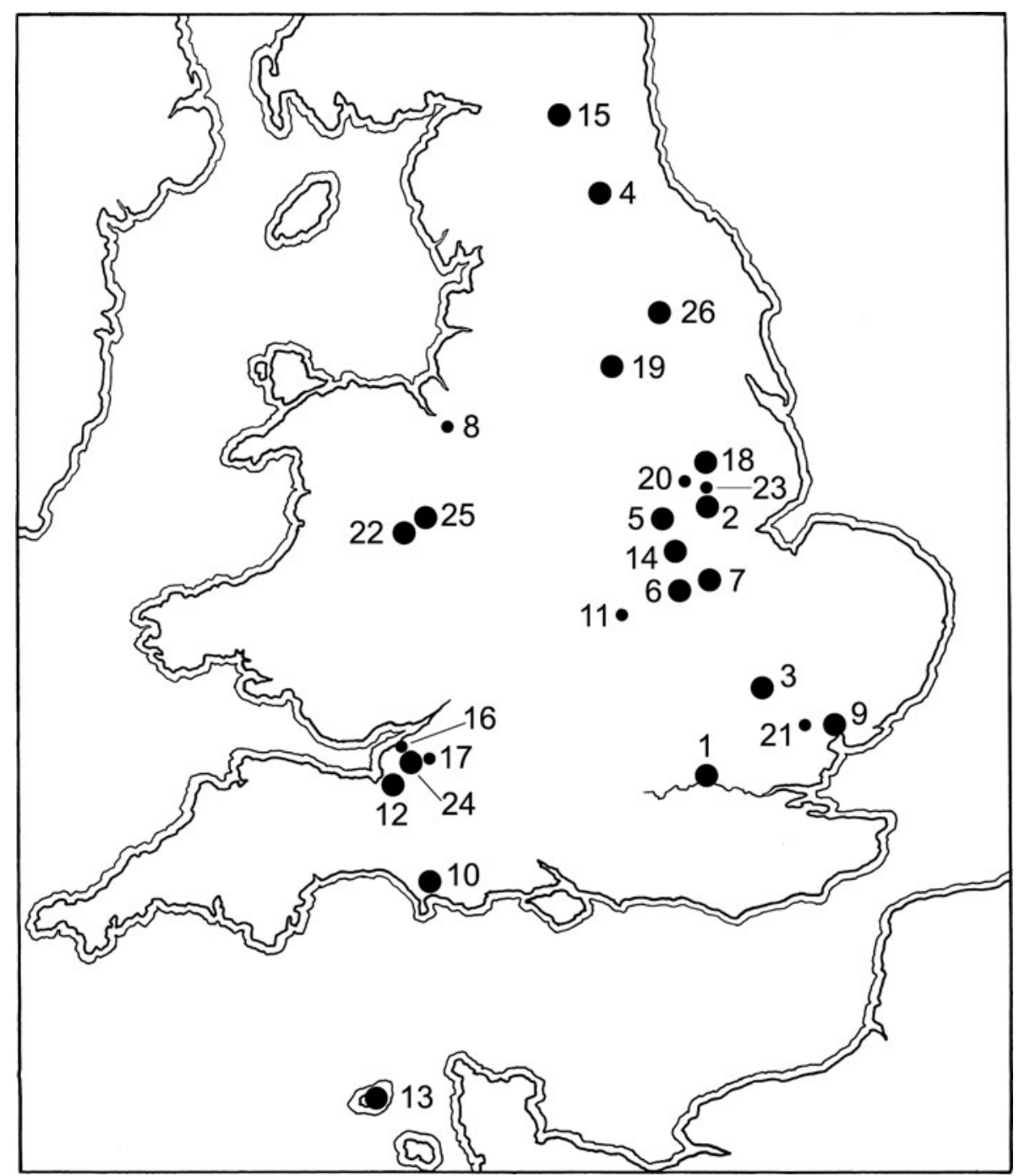

FIG. 2. Distribution map of clay moulds found in Britain, based on Boon 1988. The larger dots denote sites that had early third-century moulds: 1. London; 2. Ancaster; 3. Bartlow; 4. Binchester; 5. Bottesford; 6. Bulwick; 7. Castor; 8. Chester; 9. Colchester; 10. Dorchester; 11. Duston; 12. Edington; 13. St Peter Port; 14. Hambleton Hill; 15. Housesteads; 16. Kenn; 17. Keynsham; 18. Lincoln; 19. Lingwell Gate; 20. Nocton; 21. Rivenhall; 22. Ryton; 23. Sleaford; 24. Whitchurch; 25. Wroxeter; 26. York.

examples of Roman coin moulds. Of these, 19 sites have coin moulds for early third-century denarii (highlighted on the map). Many of the moulds were found in the nineteenth century or earlier and, as a consequence, few contextual details have been recorded and the findspots are uncertain. Most sites only have a few moulds, but Whitchurch, Somerset (FIG. 2, 24), has 350 moulds spanning a wide period, consisting of early aes and third-century aes and radiates, ${ }^{23}$ 
and Duston, Northants. (FIG. 2, 11), has 175 moulds of folles of the early fourth century. Denarii moulds of Trajan, Hadrian, Antoninus Pius and Commodus which were found at Lingwell Gate, Yorks. (FIG. 2, 19), show that earlier coins were still circulating in good condition. ${ }^{24}$ However, the moulds excavated from London Wall far outnumber those recorded from other Romano-British sites, especially considering there were many unidentified fragments in addition to those catalogued here.

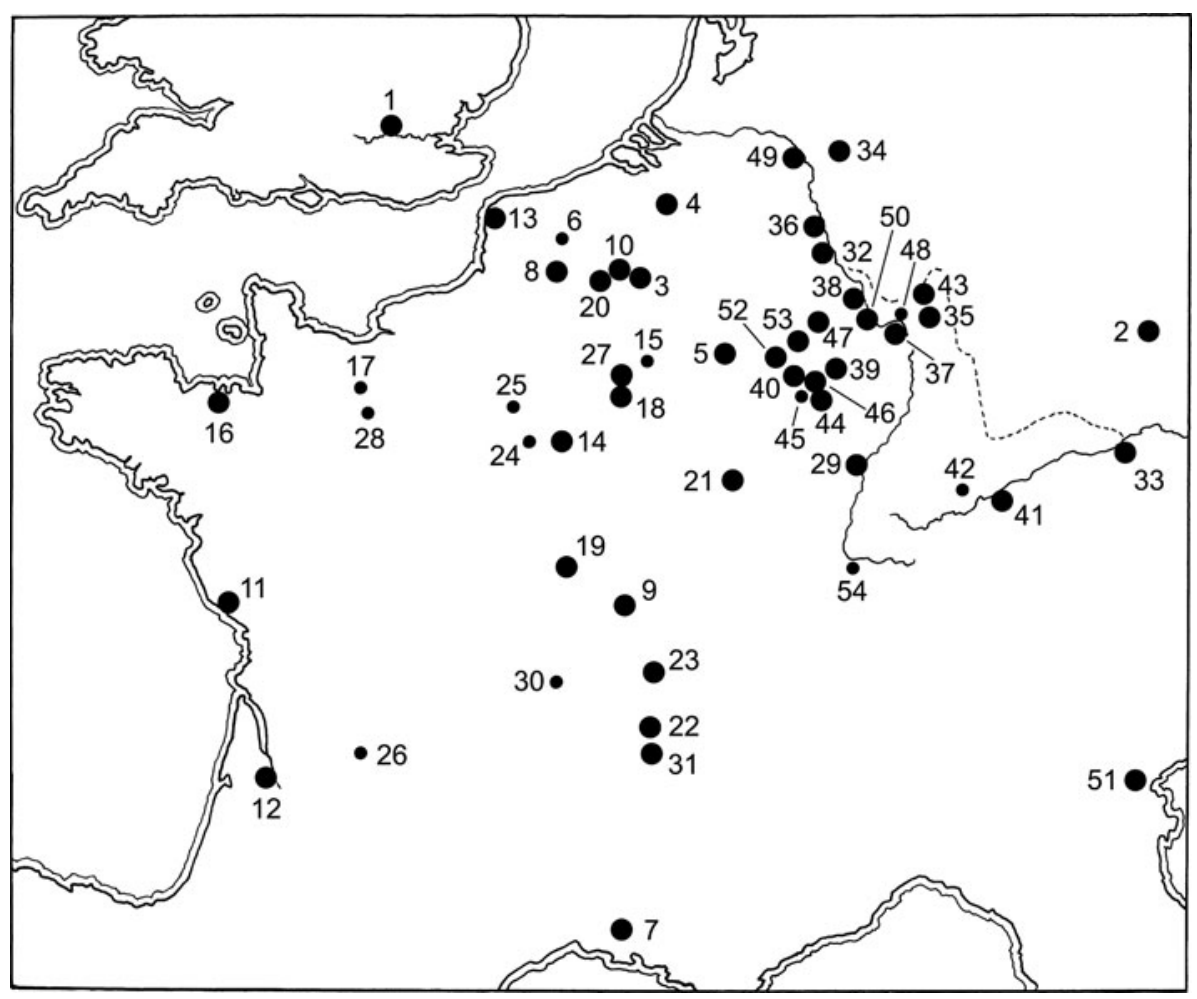

FIG. 3. Distribution of clay moulds found in Europe, based on Lallemand 1994. The larger dots denote sites that had early third-century moulds: 1. London; 2. Nieder-Osterreich; 3. Elouges; 4. Rumst; 5. Saint-Mard; 6. Tournai; 7. Arles; 8. Arras; 9. Autun; 10. Bavay; 11. Le Bernard; 12. Bordeaux; 13. Boulogne-sur-Mer; 14. Châteaubleau; 15. Château-Porcien; 16. Corseul; 17. La Coulonche; 18. Damery; 19. Entrains-sur-Nohain; 20. Famars; 21. Grand; 22. Lyon; 23. Mâcon; 24. Melun; 25. Paris; 26. Perigueux; 27. Reims; 28. Sees; 29. Strasbourg; 30. Vichy; 31. Vienne; 32. Bonn; 33. Eining; 34. Haltern; 35. Heddernheim; 36. Cologne; 37. Mainz; 38. Niederbieber; 39. Nohfelden; 40. Pachten; 41. Risstissen; 42. Rottweil; 43. Saalburg; 44. Saarbrücken; 45. Saarlouis-Roden; 46. Tholey; 47. Trier; 48. Wiesbaden; 49. Xanten; 50. Zugmantel; 51. Padova; 52. Dalheim; 53. Grevenmacher; 54. Augst.

24 See Sutherland 1937 for early finds of moulds. 
A review of clay moulds from the western part of the Roman Empire shows just how widespread these production centres were on the Continent. The information for some 54 sites was collated by Jacqueline Lallemand (FIG. 3; for details of the moulds and coin types used, see ONLINE TABLE 2). ${ }^{25}$ Some were small concerns producing only limited numbers of coins, but others were obviously on a much larger scale. In Belgium, at Saint-Mard (FIG. 3, 5), 699 moulds were excavated from a site where evidence was also found for bronze-working. From France, some 200 and over 300 moulds were recorded from Châteaubleau (FIG. 3, 14) and Damery (FIG. 3, 18) respectively. The roadside settlement at Châteaubleau was producing copies of denarii, radiates and double sestertii in the second half of the third century. Fabien Pilon has suggested that although production was organised into a number of linked officinae with several engravers, it was still most likely to be the work of forgers. ${ }^{26}$ Numerous sites in Lyon (FIG. 3, 22) each produced a few moulds, but included one site where 103 moulds were found. In Germany, 2,539 moulds were found at Pachten (FIG. 3, 40) and provided evidence for the manufacture of cast coins, as well as the presence of the clay containers. These were moulds of Antonine aes and early third-century denarii and radiates. Numerous moulds for casting early third-century coins have been found at Mainz (FIG. 3, 37) and Risstissen (FIG. 3, 41), as well as numerous sites at Trier (FIG. 3, 47) which produced over 1,000 moulds in total for the same period. It appears, therefore, that the sites with the most third-century moulds are mainly in the military provinces of northern Gaul and Germany, where there were shortages in the supply of aes coinage and where, also, a supply of silver was needed to pay the army. Although these sites show that coins were being copied throughout the Roman period, the main period of 'production' for copying silver coins was in the early to mid-third century.

\section{THE LONDON COIN MOULDS AND THE MANUFACTURING PROCESS}

The following description for producing cast coins from moulds is based on the evidence from the London moulds themselves and also on experiments conducted by conservator and experimental archaeologist, Dana Goodburn-Brown. ${ }^{27}$ Firstly, the surface of a small disc of flattened clay would have been dusted with powder and a coin pressed into the clay. Leaving the coin in place, a powdered new disc would have been placed on top and pressed down (FIG. 4). Another coin would then have been pressed into the upper surface of the second disc. This process made a double-sided mould with an obverse head of one coin on one side and a reverse of another coin on the other. The applied pressure frequently led to one impression on a double-sided mould being deeper-set than on the other and the pressure would have caused the sides and edges of the mould to expand with minuscule radial cracks evident in some surviving moulds. There is also some evidence that the 'coins' being used to make the moulds may have been either plaster casts or cast coins, rather than officially struck coins themselves. SEM images and analysis have revealed round protrusions projecting from the side of a mould, which indicate air-bubbles in the edge of the pro forma coin that was being used to make the mould. A struck coin mould would not have such features on its edge. File marks on the internal rim of some

\footnotetext{
25 Lallemand 1994.

26 Pilon 2011, 909.

27 Although her experimental work on coin blank manufacturing techniques remains unpublished, the work features in Goodburn-Brown 1998. Her full report is lodged with the moulds in the Museum of London Archaeological Archive and Research Centre.
} 
of the moulds also indicate that a cast coin or plaster copy may have been used to make some of the moulds.
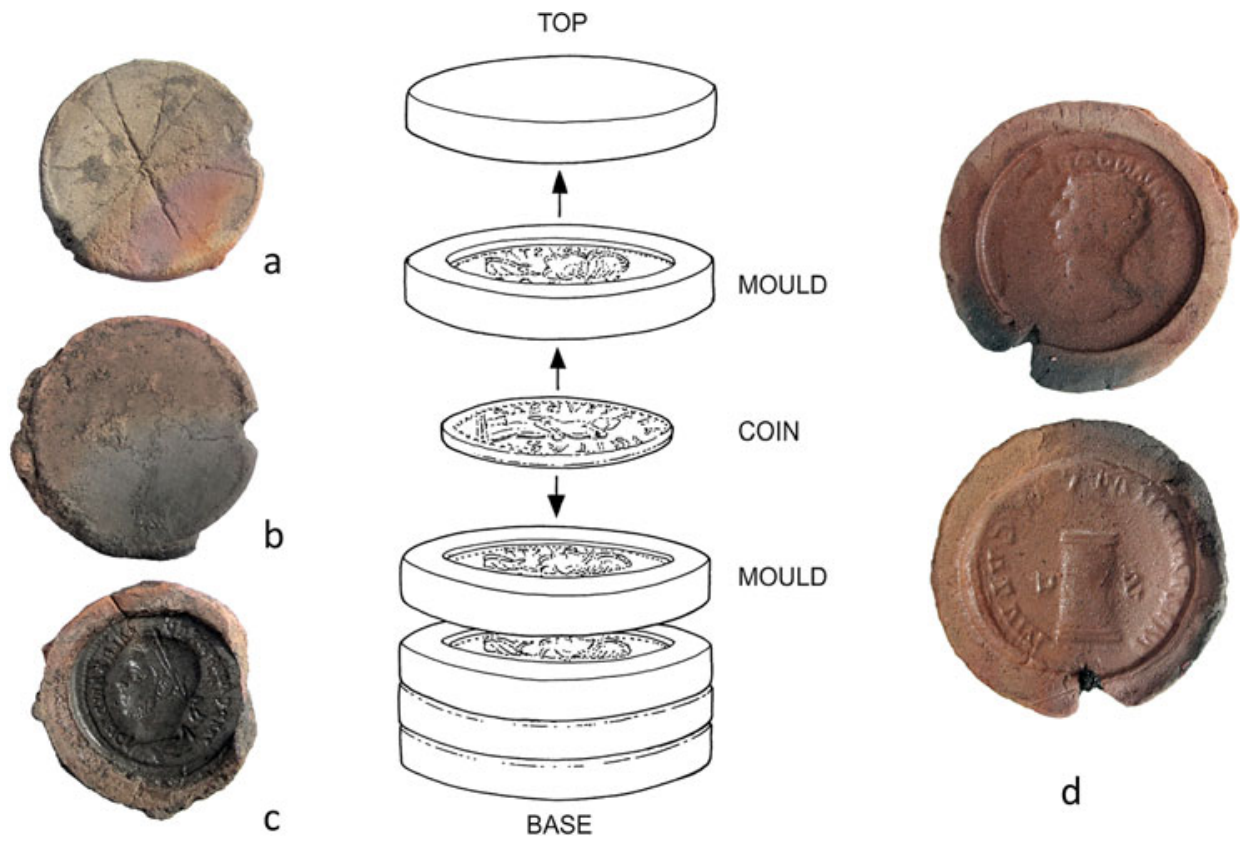

d

FIG. 4. The moulds were stacked with each one having an obverse and reverse from a coin and formed into columns. The evidence shows: (a) top mould with a scratched barred cross; (b) end mould with cutting-guide marks; (c) example of a denarius mould; (d) examples of aes moulds of Trajan (obverse) and Otacilia Severa (reverse). Scale 1:1. (Drawing by Nick Griffiths)

The process would have been repeated at least five times to form a stack or column with a single-sided mould placed at the top and bottom of each column. Once the column was assembled, it may have been lightly rolled to smooth the surface of the outer edge. A V-shaped runnel or notch would then have been cut into and down the wall of the stack, while the coins were still inside to give the column more rigidity. These runnels were sometimes extended or re-cut after the coin model was removed, to ensure the molten metal could flow into the individual moulds. In the London examples, however, the runnels of some moulds were ill-defined. From the Whitchurch evidence, it was suggested that the column would probably have been held between thumb and fingers to cut the runnels. ${ }^{28}$ The edges surrounding the notches on the London denarii moulds had been smoothed back and flattened, caused perhaps by rolling the column. Lines would then be scored along the length of the column, sometimes diagonally in criss-cross fashion, both to allow any additional layer of clay to adhere but, more importantly, to act as a means of re-positioning and aligning the moulds in the correct order. Getting them in the wrong order would have produced incorrect or hybrid coins. 
The denarii moulds vary in thickness from about 2 to $6 \mathrm{~mm}$, while the aes moulds are thicker $(4-10 \mathrm{~mm})$. Some denarii moulds are wafer-thin, and where the impressions are inset they can measure as little as $1 \mathrm{~mm}$ in depth. Indeed, there is a distinct variation between the two types and more care seems to have been taken with the denarii moulds - these are carefully finished with edges that are very smooth, straight-sided and uniform. By contrast, the aes moulds have wider rims with rounded edges that have only been partially smoothed off. It has been suggested from the evidence from both Whitchurch and Saint-Mard that the outer edge of the moulds would have been trimmed and neatened with a knife. ${ }^{29}$ This would have produced more angular sides and, while it does not seem to have been done to London's denarii moulds, the practice can be seen on some of the aes moulds where vertical ridges denote trimming marks. Evidence from some of the Whitchurch single moulds, which had a slight rim around the edge, suggests that something, perhaps a counter, might have been used as a cutting-guide. A number of the London denarii moulds also had a concentric ring impression around the rim of the blank side (FIG. 4b), which indicates something may have been pressed on the top of the column and used as a guide.

The moulds would have been left to air-dry sufficiently to allow them to be easily separated in order to remove the coin models. On some occasions it must have been difficult to separate the moulds and a sharp tool was inserted leaving gouge marks in the semi-dry clay. The impressed discs would then have been re-assembled into their columns with an obverse and reverse facing and single moulds, top and bottom. These single-sided moulds had a blank second side, some of which had a concentric ring inside the outer rim (discussed above), or scratched markings perhaps to identify the type of coin being produced. One bears a scratched barred cross, a series of intersecting diagonal lines (FIG. 4a), which Boon suggested might be the mark of a denarius column and used it to surmise that the two types of mould were being produced at the same time. ${ }^{30}$ However, the columns would have had different diameters (the denarii moulds tend to be $21-26 \mathrm{~mm}$ and the aes moulds $30-35 \mathrm{~mm}$ in diameter) and would have been easily recognisable to the trained eye of the forger. The work was obviously executed in a methodical manner since none of the double-sided moulds bear two obverses or two reverses. There seems, however, to have been no set positioning of denarii in the moulds and the runnels can be found cut at any point on the circumference. Whereas, the aes moulds, in the main where they were complete, have the notch cut at the base of the bust on the obverse (with only a variation of 10 to 20 degrees away from the vertical) which correlates with the foot, or exergue, of the imagery on the reverse side of the mould.

Having prepared the moulds, and before they could dry out completely, the columns were next encased in a more porous clay, mixed with plant material and charcoal, to form an 'outer' or 'support' mould. Many of the London moulds have some of this outer casing still attached to their edges, sometimes as much as $6 \mathrm{~mm}$ thick (FIG. 5b). Other moulds have roughened edges where the outer casing has broken off. One thin concave clay fragment has evenly-spaced horizontal lines, the width of the denarii moulds, impressed on its inner face, suggesting that a thin cylindrical wall of finer clay casing may have been necessary before a thicker rougher clay coating was applied (FIG. 5c). Several columns would then have been placed together with the notched inlets facing towards a central cavity. Based on evidence from Damery and Cologne, three columns may have been the optimum grouping and clay would then have been packed around the columns in order to make them into a container. ${ }^{31}$ At Whitchurch, this was indicated by the evidence of a layer of outer casing still adhering to the edges of the moulds. If the clay moulds in the column had been allowed to dry completely, the outer casing would not

Boon and Rahtz 1965, 36; Lallemand 1994, 143.

Boon 1988, 125-6.

Boon 1988, 109 and fig. 4. 
then have stuck to the columns - the surface of the semi-dry columns would have been dampened to allow the outer mould to adhere to the triple stack assemblage. ${ }^{32}$

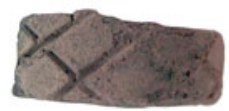

a

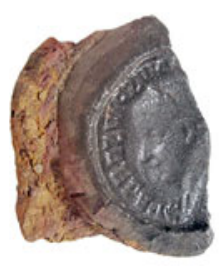

b
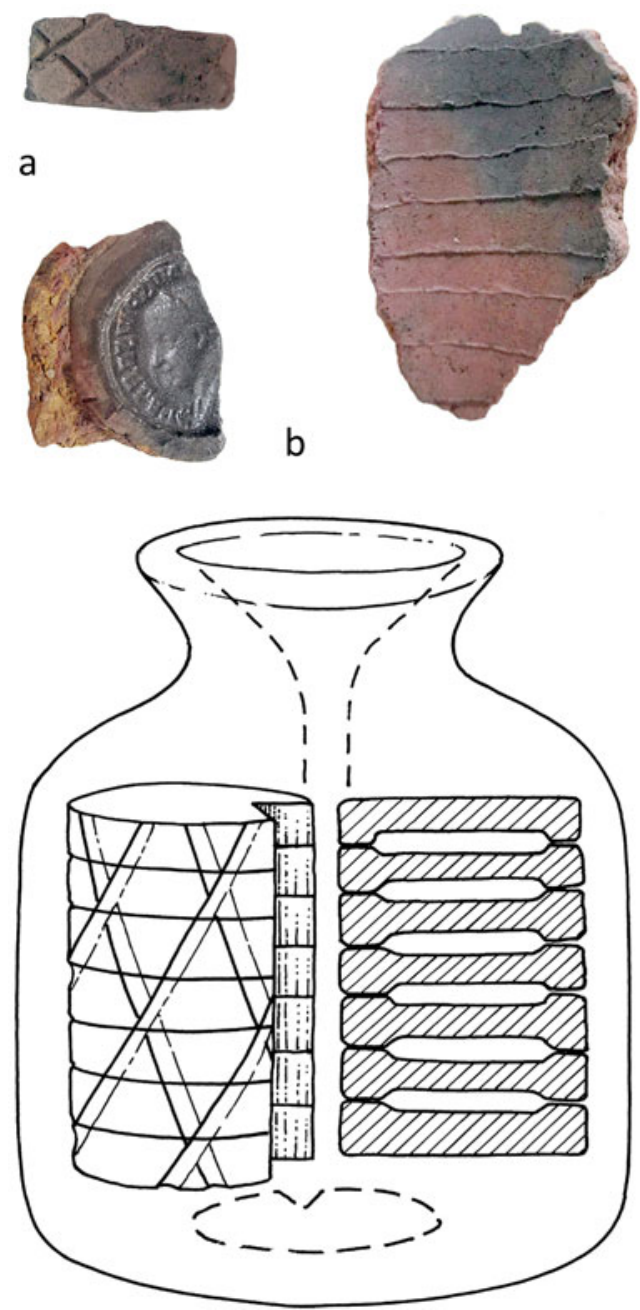

C

d
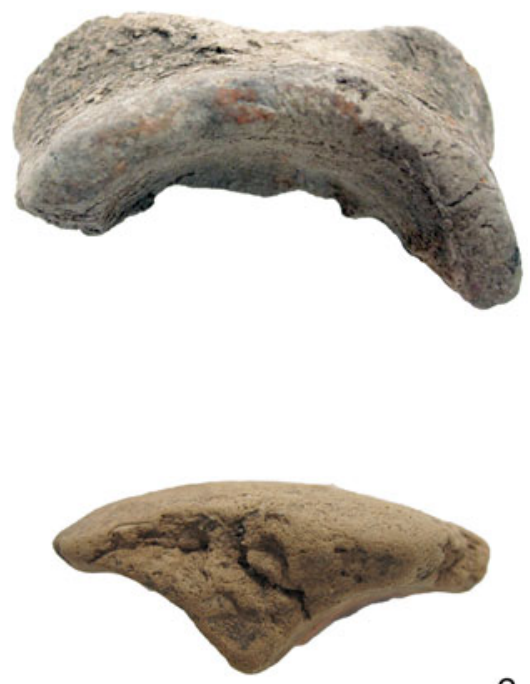

e

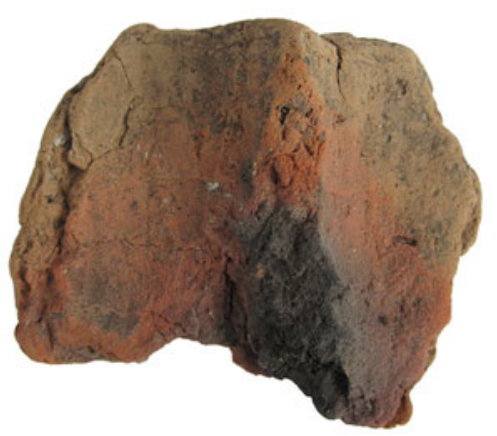

FIG. 5. The columns were placed as a trefoil with clay packed around to produce a container. The evidence shows: (a) example of scored side of denarius mould; (b) outer layer of clay adhering to a denarius mould; (c) thin clay outer layer showing denarii spacing (scale 2:1); (d) possible fragment of container neck opening; (e) fragment of outer container wall (top and side view) with triangular packing. Scale 1:1 except where specified. (Drawing by Nick Griffiths)

Clay was packed around the London columns to form a container or bottle, which was rounded on the outside to produce a cylindrical container, but with distinctive triangular sections where the rough outer-mould clay filled the spaces between the stacked columns. A number of triangular fragments of packing clay were found at London to show this to be the case (FIG. 5e). These 
pieces were orange-brown in colour through oxidisation on the outer surface, but with signs of burning on the inner surface. The container would have had a top opening fashioned like a funnel to allow the molten metal to be poured in (FIG. 5d). Several curved clay fragments survived that perhaps came from the cup-shaped opening of a container.

The molten metal would have flowed down through a central cavity and into the moulds via the triangular runnels to produce the castings (FIG. 6). Some moulds are heavily burnt or fired to a dark grey - reduced by the exclusion of the oxygen from the mould interior - while others are part-fired and some are barely scorched. As the hot metal flowed down the central cavity, the heat would have baked the moulds nearest the top and the decreasing temperature of the flowing metal caused the clay moulds to turn a variety of colours. The moulds at the base may sometimes have remained almost unfired with only an indication of burning at the notched inlet. Amongst the numerous broken fragments of moulds and outer casing, were small blackened fragments of possible burnt crucibles. The fabric of these possible crucibles contained many small inclusions of sand in order to make it more resistant to the frequent heating of the metal to the high temperatures required for casting.

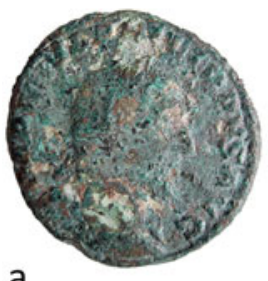

a
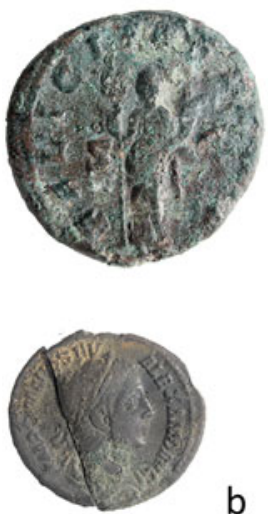

b
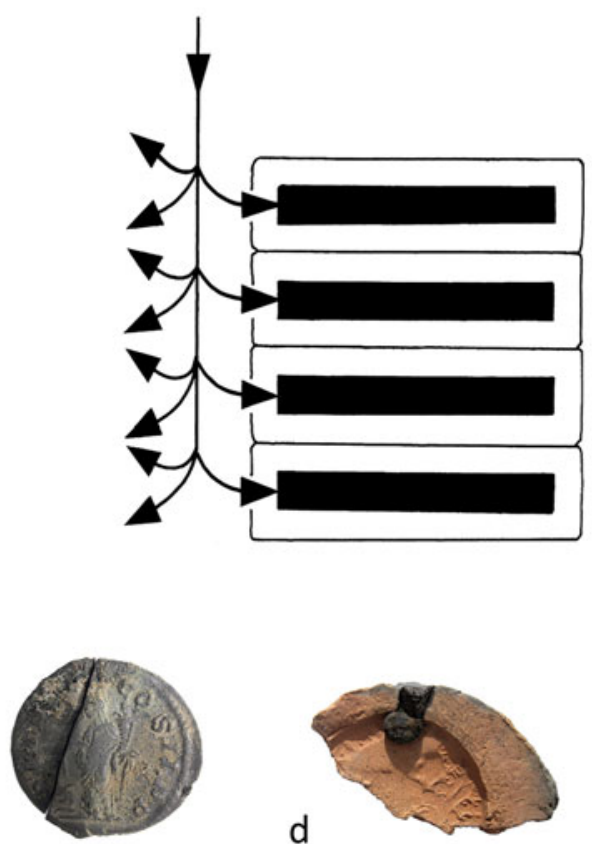

d

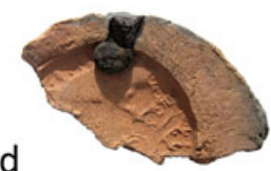

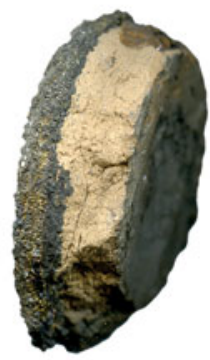

C

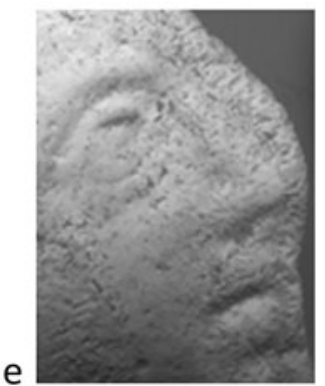

FIG. 6. The metal flowed down through a central cavity into the three columns (the arrows indicate the direction of flow into each mould). The evidence shows: (a) a hybrid copper-alloy coin (BLM87[0]<13>); (b) a cast denarius (BLM87[219]); (c) a coin stuck to a mould where the mould has been clipped away (BLM87[201]<213d>); (d) denarius mould where the molten metal formed a globule in the runnel; (e) mis-cast portion of a coin (magnified) to show the dendritic structure of cast metal. Scale 1:1 except where specified. (Drawing by Nick Griffiths) 
It is likely that the moulds were only intended to be used once, since many would have been broken when the container was smashed open during the process of removing the cast coins. A few moulds are still stuck together with mineralised traces of metal inside. Some moulds have had their edges deliberately clipped in an effort to remove the cast coin, while one clipped mould still has the cast coin attached (BLM87[201]<213d>; FIG. 6c). The forger has tried to chip the mould away, but the coin remained steadfastly in place and must then have been discarded.

\section{THE MOULD FABRIC}

The moulds for both the denarii and aes were made from a fine, micaceous clay with iron-rich inclusions, showing quartz and mica. ${ }^{33}$ It is similar to the clay used at kilns excavated at Northgate House, Moorgate in 1998. The kilns were regularly producing, amongst other wares, London oxidised ware vessels from the end of the first century and through the early second century - this ware being particularly abundant in the early Antonine period. ${ }^{34}$ The fabric of London oxidised wares is similar to that used for the moulds one hundred years later. The fine quality of the clay enabled it, in the main, to take a crisp high-quality impression.

Analysis of the outer container showed it to be the same clay, but with short lengths of straw and grass as well as small pieces of charcoal added. The charcoal would have prevented oxidisation of the cast metal and the grasses would have created sufficient porosity to allow gasses to flow out of the mould as metal was poured in. ${ }^{35}$ The moulds excavated at Saint-Mard were also made from a fine, micaceous clay, while the clay that was packed around the columns was less dense, more friable and mixed with vegetable matter. ${ }^{36}$ Similarly, the moulds from Whitchurch ${ }^{37}$ were made from a micaceous clay, with the outer casing the same as that used for the moulds, but tempered with chopped straw or grass.

\section{THE METAL USED FOR CASTING}

Cast coins were either made with a copper-alloy core and then plated or were cast using a copper-alloy mix. The metal used to make cast coins would have needed good flowing qualities that became molten at temperatures lower than the usual production temperatures for silver. Analyses of several German finds of cast denarii revealed that the casts were either a silver-tin-copper-alloy mix or copper-tin and copper-tin-lead-zinc alloys. A forged denarius from the Mainz area (FIG. 3, 37) and the evidence from moulds at Rottweil (FIG. 3, 42) showed that they had similar compositions - an alloy of silver, tin and copper (in the proportion of 60,30 , and 10 per cent) with a low melting point of about $500^{\circ} \mathrm{C}$. Moulds of third-century denarii and metal waste from Risstissen (FIG. 3, 41) in Southern Germany had a mix of copper, lead, tin and zinc (79, 10, 9, and 2 per cent), while traces of metal from the moulds consisted of copper, tin and lead (77, 20, and 3 per cent). ${ }^{38}$ In Britain, analysis of three Severan counterfeit denarii from Caerleon showed them to be a copper alloy with a high tin content of 25 per cent. ${ }^{39}$ XRF analysis of two pairs of Severan denarii moulds, excavated from a well at Chapel Hill and from between vicus buildings at Housesteads respectively, ${ }^{40}$ indicated the presence of copper, zinc and lead on the surface of the moulds.

33 Fiona Seeley, pers. comm.

34 Seeley and Drummond-Murray 2005, 114-15 and figs 148 and 153.

35 Dana Goodburn-Brown, pers. comm.

36 Lallemand 1994, 141-3.

37 Boon and Rahtz 1965, 38.

38 Raub and Zwicker 2012.

39 Boon 1988, 108 and n. 41

40 Brickstock and Casey 2009. 
Quantative XRF analysis on the London examples was conducted by Mike Heyworth (then of the Ancient Monuments Laboratory) in 1990. While no obvious metal traces were visible on the surface of the moulds, analysis revealed traces of copper and zinc on the denarii moulds and traces of copper, zinc and lead on the aes moulds. The different compounds suggest a deliberate compositional difference between the two coin types being produced.

Small fragments of mis-cast, spoilt and cut coins showed that the metal did not always flow properly into the moulds. Spoilt castings had been made of gunmetal (a copper that contained significant levels of zinc and tin) and the dendritic structure which represents cast metal is very clear on the surface of one of the mis-cast portions (FIG. 6e). The coin, found still attached to its mould (BLM87[201]<213d>; FIG. 6c), was made of a copper alloy (bronze) that contained small traces of lead, whilst a cast hybrid coin (a coin that had the wrong reverse matched with the obverse), found elsewhere on the same site, was also made of a copper alloy that contained small traces of lead (BLM87[0]<13>; FIG. 6a and Appendix 3). The latter coin, being a cast, had a seam around its edge, which showed that it came from two moulds; one with a deep impression; the other, more shallow. This may have been intentional, since it would have left a seam-line close to the top edge, thus making it less detectable as a forgery. A cut denarius (BLM87[219]; FIG. 6b and Appendix 3) - found later amongst the moulds and, therefore, not included in the metal analysis - has a seam-line along its edge, clearly showing that it was cast. An area on the edge of this coin also shows the 'casting-cup', where the metal had flowed into the mould. This would have been left attached until the metal had cooled and hardened and was then cut off leaving a flattened area at that point.

\section{DISCUSSION}

To be able to calculate the number of coins that the forger had in his possession requires being able to match obverses with reverses. A double-sided coin mould has the obverse of one coin and the reverse of another. As the moulds were mostly found loose and unconnected, the matching up process is complicated, especially with denarii of the Severan family which often have the same reverse types. Added to which, the moulds are in reverse and, thus, are more difficult to identify. It has not been possible to reach a final total of coins used, since there were many unidentifiable small fragments in addition to those included here. However, at least 61 denarii reverses were recorded (Appendix 1), some of these having been produced from more than one coin with the same reverse. There would have been some 16 aes coins.

It has been possible to identify 814 single- and double-sided complete or fragmentary moulds, excepting the numerous small fragments that it has not been possible to identify with any certainty (Table 1). There were 400 double-sided and 75 single-sided denarii moulds (of which 26 were obverses and 49 reverses) and one possible single-sided radiate mould. For casting aes, there were 246 double-sided and 92 single-sided moulds (of which 40 were obverses and 52 reverses). Boon ${ }^{41}$ noted that it might be possible to calculate how many moulds were in each column by the ratio of single-sided to double-sided moulds recorded. He gave, as an example, the number of single-sided $(302)$ to double-sided moulds $(1,134)$ from Pachten calculating that there might have been 8 or 9 moulds per stack, and 12 at Damery. At London, the number of single-sided denarii moulds would denote some 39 columns with about 10 double-sided moulds in each column. There are rather more single-sided aes moulds in proportion to the double-sided examples which, even allowing for these moulds being thicker, would have meant only five double-sided moulds in each column, with perhaps some 50 columns in total. Indeed, experiments showed that five or six were perhaps the optimum. There must have been many

41 Boon 1988, 152, n. 43. 
more London moulds, such as those seen on the edge of the site which were inaccessible to the archaeologists and have failed to survive or still await discovery.

TABLE 1. NUMBER OF COIN MOULDS FOUND FROM LONDON WALL

\begin{tabular}{|c|c|c|c|c|c|}
\hline Emperor & Denarii & Dupondii & Asses & MoL moulds & Private ownership \\
\hline Trajan & & & 25 & $1(\mathrm{AE})$ & \\
\hline Antoninus Pius & & & 7 & & \\
\hline Faustina I & 1 & & & & \\
\hline Faustina II & & & 5 & $3(\mathrm{AE})$ & \\
\hline Septimius Severus & 54 & & & & \\
\hline Julia Domna & 49 & & & $1(\mathrm{AR})$ & \\
\hline Geta & 4 & & & & \\
\hline Caracalla & 27 & & & & \\
\hline Caracalla/Elagabalus & 4 & & & & \\
\hline Elagabalus & 94 & & & & \\
\hline Julia Maesa & 25 & & & & \\
\hline Julia Soaemias & 3 & & & & \\
\hline Julia Paula & 7 & & & & \\
\hline Severus Alexander & 84 & 3 & & & \\
\hline Julia Mamaea & 59 & & & & \\
\hline Orbiana & 4 & & & & \\
\hline Maximinus & 8 & 12 & 12 & $1(\mathrm{AE})$ & \\
\hline Balbinus & 1 & & & & \\
\hline Gordian III & 1 & & 15 & $1(\mathrm{AE})$ & \\
\hline Philip I & & & 31 & $8(\mathrm{AE})$ & \\
\hline Otacilia Severa & & & 50 & $5(\mathrm{AE})$ & \\
\hline Trajan Decius & & & 28 & $2(\mathrm{AE})$ & \\
\hline Herennia Etruscilla & & & 59 & $7(\mathrm{AE})$ & $1(\mathrm{AE})$ \\
\hline Trebonianus Gallus & & & 9 & $1(\mathrm{AE})$ & $1(\mathrm{AE})$ \\
\hline \multirow[t]{2}{*}{ Reverse only } & 48 & & 50 & $1(\mathrm{AR})$ & \\
\hline & & & & $2(\mathrm{AE})$ & \\
\hline Uncertain & & 1 & & $1(\mathrm{AE})$ & \\
\hline TOTAL: 814 & 473 & 16 & 291 & 34 & \\
\hline
\end{tabular}

Table 1 shows the number of coin moulds and coin denominations grouped by emperor. Numbers are taken from the surviving evidence discovered during the excavation, those moulds later acquired by the Museum of London and those of a private collector (not included in the count). As can be seen, the coins used to make the moulds were silver denarii of the Severan family (A.D. 194-238), Maximinus, Balbinus and Gordian III (A.D. 238-44); there is just one single-sided mould that, from the size and possible radiate obverse impression (listed as uncertain dupondius in Table 1 above), may possibly be that of a radiate, but it is too heavily burnt and abraded to be able to identify it further. Another mould, more rounded on its surface and with a clear but shallow impression less likely to produce a decent cast, was taken from a denarius of Faustina I, minted after her death, with a reverse of Vesta (see Appendix 1, Reverse type 39, RIC 400). This was perhaps a trial piece, for it would never have worked as a mould and is unused.

The aes moulds were made from very worn copper-alloy coins of Trajan (A.D. 98-117), Antoninus Pius (A.D. 138-61) and Faustina II (mid-second century), a copper-alloy as and radiate dupondius of Severus Alexander, asses and dupondii of Maximinus, and asses of Gordian and the emperors dating from A.D. 238 to 253. These coins give some indication of the length of time that some coins must have remained in circulation. It is known, for example, that sestertii from Vespasian onwards are still found in hoards dating as late as Postumus.

Apart from the worn second-century aes and the denarius of Faustina I, therefore, the bulk of the moulds come from coins that date from A.D. 194-253 and cover the main emperors with only a 
few minor exceptions. The reverses are listed in Appendix 2 divided into denarii and aes types, but it is interesting to note that one reverse aes mould (Appendix 1, AE4), although fragmentary, seems to be from a third-century coin from the Macedonian mint of Pella. The coins used to make the moulds, both denarii and the later aes, were mainly in good condition, although some are more worn than others, and it would seem that the forgers were at work in the mid- to late third century.

\section{COMPARATIVE LONDON MATERIAL}

Only two other sites have revealed moulds within Roman London. At Newgate Street in 1966 (GM131, FIG. 1; Central Criminal Court), ${ }^{42}$ two double-sided denarii moulds were found buried in rubbish that had accumulated in the stairwell of an internal turret of the city wall, which enabled archaeologists to suggest a date of A.D. 200 for the building of the city wall. They were found with an almost mint-condition denarius of Caracalla of A.D. $213-17^{43}$ and earlier bronze coins - an as dating to A.D. $143-44,{ }^{44}$ a sestertius of Antoninus Pius dating to A.D. 145-61, ${ }^{45}$ and an as of Commodus dating to A.D. 180-92. ${ }^{46}$ The moulds consisted of obverses from coins of both Septimius Severus (A.D. 201-10) and Geta (A.D. 210-12). ${ }^{47}$ They each had an identical reverse from a coin of Caracalla dating to A.D. $215,{ }^{48}$ with the figure of Aesculapius and the reverse legend, $\mathrm{P}$ M TR P XVIII COS IIII P P. The very worn copper-alloy coins were considered by Merrifield to be raw material for melting down to produce new casts. He suggested that the forger, holding three new coins issued between A.D. 210 and 217, would have been at work between c. A.D. 215 and 225.49

Three other double-sided denarii moulds were excavated from a ditch in Bermondsey Square (BYQ98; FIG. 1) by Pre-Construct Archaeology in 1998. One complete mould (BYQ98[9188] $<622>$ ) shows an obverse of a bearded and laureate Severan emperor, but only traces of a legend. The reverse type of Marti Propugnatori, showing Mars hurrying left, holding a spear and trophy, appears on a denarius of Caracalla, ${ }^{50}$ struck between A.D. 210 and 213. Two other fragmentary moulds (BYQ98[9190]<946>) seem to have the same reverse. ${ }^{51}$

The reverse types on the Newgate and Bermondsey Square examples have no parallels with the London Wall moulds. The clay of these other moulds, although containing mica, is not identical to that of the London Wall examples and, although they are manufactured in a similar fashion, they differ in size and thickness. All the London sites, however, show that the moulds were thrown away where it was hoped that they would never be discovered. In the case of the Bermondsey eyot, as well as the other islands south of the river that flooded at high tide, the land was gradually reclaimed and it may have been an area used for farming during the Roman period.

As has been mentioned above, the closest parallels to the London Wall find come from Saint-Mard in Belgium and Pachten in Germany. Lallemand describes, in particular, the find from Saint-Mard where a total of 37 coins (4 radiates, 7 denarii, 15 sestertii, 11 asses and/or dupondii) were used to make 699 moulds. Unlike London, though, these moulds were in the

\footnotetext{
Schofield and Maloney 1998, 75.

MoL Acc. No.: 92.41/25.

MoL Acc. No.: 92.37/17.

MoL Acc. No.: 92.37/4.

MoL Acc. No.: 92.39/7.

MoL Acc. Nos: 24290 and 24291.

RIC Caracalla, 251.

Merrifield 1983, 160-3.

RIC Caracalla, 223.

Douglas and Haslam forthcoming.
} 
main, single-sided. Only eight were double-sided. ${ }^{52}$ The numerous coin moulds from Pachten in Germany also cover a wide period. Over 140 coins (including 1 radiate, 114 denarii, 2 sestertii, 19 asses) were being used to produce hundreds of copies with a total of 1,134 double and 302 single moulds found ${ }^{53}$ - a forger on a much larger scale than London. Some of the Pachten moulds were still stuck together and had the remains of the columns and some of the clay container still surviving with the triangular-sectioned packing. The moulds were a mix of early asses and sestertii, issued under Marcus Aurelius, consisting of the deified Antoninus Pius (1 sestertius), Marcus Aurelius (1 as), Lucius Verus (2 asses), Faustina II (1 denarius), and Commodus (1 as). The earliest mould was of an as of Marcus Aurelius (A.D. 164-65). The greatest proportion, however, were of denarii which dated between A.D. 193 and 235, starting with Severus. This is similar to the London Wall moulds. The German moulds cover the same emperors, but include Plautilla and Macrinus, not covered by the London moulds. There was a radiate and an as of Gordian III and one radiate a-piece of Philip I, Trajan Decius, Gallienus and Valerian II. The production date was thought to be A.D. 258-60. While the Pachten moulds cover the same period, there is no use made of the later aes coinage that features in the London find. To date, no other sites in Roman Britain or the North-Western provinces have revealed moulds for the production of the copper-alloy coins of the mid-third century. As discussed above, the information from the Portable Antiquities Scheme shows that dupondii and asses appear regularly on Romano-British sites in the third century, although they are certainly less common than second-century issues. General scarcity might have provided the motivation for counterfeiting and it would probably have not been too difficult to obtain the sixteen coins used for the London aes moulds.

It must have been difficult for the forger to check whether he was matching the right obverse with reverse when re-assembling the columns of moulds. Was he careful or not? Clues to their carefulness/carelessness were found amongst the moulds. A cast denarius of Severus Alexander with a reverse type of Annona (BLM87[219]; FIG. 6b and Appendix 3, Reverse type AR54) is correct and an obverse of an as of Otacilia Severa stuck to what would have been the reverse of the mould, also had an obverse mould of Otacilia Severa on the other side (FIG. 6c). The forger had ensured that the moulds were assembled in the correct order. However, a cast as of Philip I found elsewhere on the site, had a reverse type of Gordian III and may have been a more careless product of the forger (BML87[0]<13>; FIG. 6a and Appendix 3). A simple metallurgical test of the surface of the latter coin shows it to be heavily leaded making it easier to cast (see above). Having the incorrectly-matched obverse and reverse shows that the forger did not necessarily bother to ensure that each cast coin conformed to the official coinage. However, one only has to consider the loose change of today to realise that people rarely recognise fakes, unless they handle differently.

Further research should be carried out on London's coins for the period with regard to counterfeiting practices. There are many denarii of the early third century in the Museum of London's reserve collections. Also, a hoard of 142 low-quality denarii in private ownership, for example, thought to be from the site of Billingsgate Lorry Park (BWB83; a watching-brief conducted by Museum of London Archaeology in 1983) had a concentration of a very few types. ${ }^{54}$ The bulk (122) of the coins had a reverse of PROVID AVGG, while seven had LIBERTAS AVG (Appendix 1, Reverse type AR19), which strongly suggests a forger's stock. Certain of the other reverses (Reverse type AR21: Monet Aug; Reverse type AR25: Pietas Publica; and Reverse type AR31: Saeculi Felicitas) are similar to the existing moulds, while others are not. The hoard comprises coins featuring Marcus Aurelius, Septimius Severus, Julia

52 Lallemand 1994.

53 Alfoldi 1974.

54 Hall 1986. 
Domna, Caracalla and Geta. Unfortunately, the hoard was only available to the writer for a short time and it was not possible to establish the quality of the metal. The coins were in a good state of preservation and showed little signs of wear suggesting that they had been produced and deposited in the early third century. Any future work needs to study London's archaeological collections, published hoards and the Portable Antiquities Scheme to calculate the proportion of official to unofficial coins.

\section{CONCLUSION}

The coin moulds, especially the denarii moulds, were carefully made. The moulds are, in the main, thin, carefully impressed and finished off with neat smoothed edges indicating the careful rolling of the assembled columns with the notches perhaps being cut into the moulds while in the column and the clay edge either side of the notch being re-flattened after the notch was cut. The aes moulds are thicker and the finished edges cruder, less smooth and probably finished using a knife. Do these differences indicate that we have different forgers producing the denarii and aes coinage or the same forgers perhaps working at different times?

Here we have forgers working on quite a large scale. Not only did they need a supply of coins for copying, but also the basic raw materials. They had in their possession at least 61 silver denarii and 16 copper-alloy coins - enough to produce a varied selection of counterfeit coins. The number of coins, compared with the annual salary of a soldier at the time (under Caracalla, for example, this was in the region of 675-900 denarii), ${ }^{55}$ makes it seem that it was a relatively small tranche of money, but perhaps not an inconsiderable sum to the forger. The forgers also needed a supply of suitable clay for the moulds, as well as access to metalworking facilities. Metalworking has been found at various sites in the City and Southwark, although industry, in general, was concentrated in workshops in the middle to upper Walbrook valley. ${ }^{56}$ There, the knowledge and technology would have been available to produce cast coins of a reasonable quality and in an area not too far from where the coin moulds were deposited. There is no shortage of evidence, therefore, that these forgers were able to produce counterfeit coins in some numbers.

The explanation for such an extensive casting of denarii is unclear. It may represent simple forgery, or perhaps it was an attempt to increase the numbers of the smaller silver denomination at a time when it was being dominated by the new radiates. A need to produce small change seems the likely explanation for the moulds of dupondii and asses; such coins did not circulate in significant numbers in Britain, and, while moulds, such as the ones from London, would have had little effect on the stock of smaller denominations in circulation, they do seem to attest a desire to provide some in Roman Britain. This gives us a surprising insight into the nature of the monetary economy of third-century Britain, and implies that coin use could have extended to smaller transactions than we might otherwise have thought. Reece — while pointing out that Roman coinage remained relatively stable from the late first to mid-third century, the period of the London Wall moulds - felt that cast denarii of the early third century were made to look real with the intent to deceive. ${ }^{57}$ London must have seen numerous counterfeit coins in circulation in the third century and it seems to have been a major producer for Britain, comparing well with Saint-Mard in Belgium, and Pachten and Trier in Germany, as well as other military frontier sites. The coins, of relatively low value, were just small change and, it would have been thought, hardly worth the effort of forging. Reece has suggested that the gap in the supply of

\footnotetext{
55 Speidel 1992, 113-23. Under Domitian, soldiers were paid 300 denarii per annum which had risen perhaps to 450 or 600 denarii under Septimius Severus and had more than doubled to either 675 or 900 denarii under Caracalla.

56 Hall 2005, 129-32.

57 Reece 2002, 45.
} 
official aes may have begun to affect London's important trading capabilities and that, as the centre of finance for the province, ${ }^{58}$ it must have felt the lack of coins more acutely.

The moulds are an important and unusual collection for Roman London. Only five other such moulds for the production of silver denarii have been found in London, two of which were also found buried amongst rubbish that had accumulated against the inside of the city wall, while three were found in an agricultural ditch. The moulds from London Wall were scattered radiating out over a wide area as a result of water action - amongst rubbish in the city ditch, as were the moulds from the turret at Newgate. This hardly seems the place to discard them if this was a semi-official process, but then rubbish was generally deposited all over the city.

The construction of the city wall is usually postulated to be $c$. A.D. 200. This is partly based on the evidence of the Newgate moulds, which were dated to $c$. A.D. 220-25 and, allowing for some 20 years of rubbish to accumulate under the stairwell of an internal turret, provided a construction date for the wall of $c$. A.D. 190-220. ${ }^{59}$ The bulk of the London Wall moulds spanned some 50 years from A.D. 194 to 253 , which would indicate a deposition date for these moulds of post A.D. 253. The moulds were excavated from the contents of the upper levels of the city ditch. Some moulds are water-worn and must have been lying in the ditch for some time, which may account for the fragmentary nature of the evidence. This might, therefore, give a deposition date of $c$. A.D. 260 or later.

Although it is tempting to suppose that the forger had been discovered and that there was a need to dispose of the incriminating evidence hastily, current thought seems to regard forging as a necessary evil when certain coins were in short supply. So, should we be regarding this as a criminal act at a time of high inflation or merely a recognised method of increasing the coin supply?

\section{APPENDIX 1. THE REVERSE TYPES OF COINS FOUND ON THE MOULDS}

The reverse types of the coins found on the moulds are listed by legend and description and are identified by AR for denarii moulds and AE for aes moulds. Reverses are assigned a RIC (Roman Imperial Coinage) number where this can be identified. Many reverses can be assigned to several emperors and empresses and these are indicated here. One reverse has a BMC (British Museum Catalogue) reference.

\begin{tabular}{|c|c|c|c|}
\hline & $\begin{array}{c}\text { Denarii }(\mathrm{AR}) \text { reverse } \\
\text { legends }\end{array}$ & $R I C$ coin description & Possible $R I C$ reference numb \\
\hline AR1 & $\begin{array}{l}\text { ABVNDANTIA } \\
\text { AVG }\end{array}$ & $\begin{array}{l}\text { Abundantia, stg 1, emptying } \\
\text { cornucopiae; in field, star }\end{array}$ & $\begin{array}{l}\text { Elagabalus } R I C 56 \\
\text { Severus Alexander RIC } \\
184 \mathrm{a}\end{array}$ \\
\hline AR2 & $\begin{array}{l}\text { ADVENTVI AVG } \\
\text { FELICISSIMO }\end{array}$ & $\begin{array}{l}\text { Emperor riding } r \text {, hand } \\
\text { raised }\end{array}$ & Septimius Severus RIC 74 \\
\hline AR3 & AEQVITAS AVG & $\begin{array}{l}\text { Aequitas, stg } 1 \text {, holding } \\
\text { scales and cornucopiae }\end{array}$ & $\begin{array}{l}\text { Severus Alexander RIC } 126 \text {, } \\
185 \text { or } 274\end{array}$ \\
\hline AR4 & ANNONA AVG & $\begin{array}{l}\text { Annona, stg } 1 \text {, holding corn } \\
\text { ears over modius and cornucopiae }\end{array}$ & $\begin{array}{l}\text { Severus Alexander RIC } 133 \text {, } \\
187 \text { or } 230 \\
\text { Julia Soaemias RIC } 234\end{array}$ \\
\hline AR5 & $\begin{array}{l}\text { ARAB ADIAB COS } \\
\text { II P P }\end{array}$ & $\begin{array}{l}\text { Victory advancing } 1 \text {, holding } \\
\text { wreath and trophy }\end{array}$ & $\begin{array}{l}\text { Septimius Severus RIC } 58 \text {, } \\
63 \mathrm{~A}, 64 \text { or } 76\end{array}$ \\
\hline
\end{tabular}


Denarii (AR) reverse legends

AR6 CONCORDIA

AR7 CONCORDIA AVGG

AR8

DIANA LUCIFERA

AR9

FECVND

AVGVSTAE

AR10

FELICITAS PVBLICA

AR11 FELICITAS PVBLICA

AR12 FIDES MILITVM

AR13 FIDES MILITVM

AR14 FIDES PVBLICA

AR15 INVICTVS

SACERDOS AVG

AR16 IOVI

CONSERVATORI

AR17 IOVI

PROPVGNATORI

AR18 LIBERALITAS

AVG IIII

AR19 LIBERTAS AVG

AR20 MARS VICTOR

AR21 MONET AVG

AR22 PACI AETERNAE

AR23 PAX AVGVSTI

AR24 PIETAS AVGG

\section{$R I C$ coin description}

Concordia, seated 1 , holding out a patera

Concordia, seated 1 , holding patera and double cornucopiae

Diana, stg 1, crescent on neck, holding torch in both hands

Fecunditas, stg 1, holding hand over a child and holding patera and cornucopiae Felicitas, seated 1, holding caduceus and cornucopiae Felicitas, stg front, head 1, legs crossed, holding caduceus and leaning $1 \mathrm{arm}$ on column Fides, stg 1, holding a standard on either side Aquila between 2 standards with shields at base Fides, stg r, holding cornears and basket of fruit Elagabalus, stg 1, sacrificing over tripod, holding patera and club; star in field Jupiter, stg 1, naked but for mantle on shoulders, holding thunderbolt and sceptre

Jupiter, hurrying $\mathrm{r}$, brandishing thunderbolt and raising 1 hand wrapped in cloak

Liberalitas, stg front, head 1, holding abacus and cornucopiae Libertas, stg 1, holding pileus and sceptre; star in field

Mars, naked with cloak flying, advancing $r$, holding spear and trophy

Moneta, stg 1, holding scales and cornucopiae Pax, seated 1, holding branch and sceptre Pax walking 1 , holding olive branch and sceptre Pietas, stg 1, raising both hands, altar at feet
Possible $R I C$ reference number

Julia Paula RIC 211

Julia Paula RIC 216

Julia Maesa RIC 277

Julia Mamaea RIC 330

Orbiana RIC 319

Balbinus RIC 1

Julia Domna RIC 548, 638 or $373 \mathrm{~A}$

Julia Mamaea RIC 331

Julia Maesa RIC 251

Julia Mamaea RIC 338

Julia Mamaea RIC 335

Gordian III RIC 128

Julia Maesa RIC 278

Severus Alexander RIC 139

Elagabalus RIC 78

Caracalla RIC 19

Elagabalus RIC 79

Elagabalus RIC $87-8$ or 191

Severus Alexander RIC 141, 198 or 200

Balbinus RIC 2

Septimius Severus RIC 131 or 270

Severus Alexander RIC 201 or 230-6

Elagabalus RIC 104

Septimius Severus RIC 280 Elagabalus RIC 107-8

Severus Alexander RIC 155 or 285-7

Elagabalus RIC 121 or 123

Septimius Severus RIC 484

Julia Domna RIC 609

Septimius Severus RIC

$118 \mathrm{~A}$

Elagabalus RIC 125

Maximinus RIC 12 or 19

Julia Domna RIC 573 


\begin{tabular}{|c|c|}
\hline AR25 & $\begin{array}{c}\text { Denarii (AR) reverse } \\
\text { legends } \\
\text { PIETAS PVBLICA }\end{array}$ \\
\hline AR26 & PRINC \\
\hline & IVVENTVTIS \\
\hline AR27 & PROVID DEORVM \\
\hline AR28 & $\begin{array}{l}\text { PROVIDENTIA } \\
\text { AVG }\end{array}$ \\
\hline AR29 & $\begin{array}{l}\text { PROVIDENTIA } \\
\text { AVG }\end{array}$ \\
\hline AR30 & PVDICITIA \\
\hline
\end{tabular}

\begin{tabular}{|c|c|}
\hline AR31 & $\begin{array}{l}\text { SAECVLI } \\
\text { FELICITAS }\end{array}$ \\
\hline AR32 & $\begin{array}{l}\text { SECVRITAS } \\
\text { PVBLICA }\end{array}$ \\
\hline AR33 & $\begin{array}{l}\text { TEMPORVM } \\
\text { FELICITAS }\end{array}$ \\
\hline AR34 & VENERI FELICI \\
\hline AR35 & $\begin{array}{l}\text { VENVS } \\
\text { CAELESTIS }\end{array}$ \\
\hline AR36 & VENVS GENETRIX \\
\hline AR37 & VENVS VICTRIX \\
\hline AR38 & VENVS VICTRIX \\
\hline AR39 & VESTA \\
\hline
\end{tabular}

AR40 VICTOR ANTONINI AVG

AR41 VICTORIA AVG

\section{$R I C$ coin description}

Pietas, veiled, stg front, head 1 , by altar raising both hands

Emperor, stg 1, holding branch or baton; trophy $r$ Providentia, stg 1, holding wand over globe and sceptre or cornucopiae

Providentia, stg 1 , holding corn-ears and cornucopiae; modius on ground Providentia, stg 1, holding wand over globe

Pudicitia, veiled, seated $1, \mathrm{r}$ hand on breast, 1 on arm of chair

Felicitas, stg 1, sacrificing with dish over lighted altar and holding long caduceus; star in field Securitas, seated 1, holding globe, 1 arm on chair

Felicitas, stg 1, holding caduceus and cornucopiae Venus, stg r, holding sceptre and cupid

Venus, seated 1, holding apple and sceptre; before her, child

Venus, stg 1, holding apple and sceptre; at feet, cupid

Venus, stg 1, holding helmet and transverse sceptre; at feet 1 , shield

Venus, stg 1, holding helmet and palm, resting on column Vesta, stg 1, holding palladium and sceptre

Victory advancing $r$, holding wreath and palm

Victory running 1, holding wreath and palm

\section{Possible $R I C$ reference number}

Julia Domna RIC 574 or

643

Geta $R I C 14$

Caracalla RIC 38A

Geta RIC 18 or 106

Geta RIC 51

Severus Alexander RIC 250

Septimius Severus RIC 92A Severus Alexander RIC 173 Maximinus RIC 13 or 20

Julia Domna RIC 575, 576 or 385

Julia Paula RIC 221A

Julia Soaemias RIC 238

Julia Maesa RIC 268

Julia Mamaea RIC 347

Orbiana RIC 324

Julia Soaemias RIC 239

Julia Maesa RIC 272

Julia Mamaea RIC 348

Orbiana RIC 325

Septimius Severus RIC 56

or 93

Caracalla RIC 332

Elagabalus RIC 150

Severus Alexander RIC 179

Julia Mamaea RIC 351

Julia Soaemias RIC 243

Julia Domna RIC 389B

Julia Mamaea RIC 355-6

Septimius Severus RIC 328

Julia Maesa RIC 275

Julia Mamaea RIC 358

Julia Domna RIC 581

Faustina I RIC 400

Julia Paula RIC 224

Julia Maesa RIC 276

Julia Mamaea RIC 360

Septimius Severus RIC

328A

Elagabalus RIC 153 or 156

Severus Alexander RIC 180 


\begin{tabular}{|c|c|c|c|}
\hline & $\begin{array}{c}\text { Denarii }(A R) \text { reverse } \\
\text { legends }\end{array}$ & $R I C$ coin description & Possible $R I C$ reference number \\
\hline AR42 & $\begin{array}{l}\text { VICTORIA } \\
\text { AVGVSTI }\end{array}$ & $\begin{array}{l}\text { Victory with her foot on a } \\
\text { helmet, writing VOT X on a } \\
\text { shield }\end{array}$ & Severus Alexander RIC 219 \\
\hline AR43 & P M TR P II COS P P & $\begin{array}{l}\text { Salus, seated } 1 \text {, feeding } \\
\text { snake coiled round altar }\end{array}$ & Severus Alexander RIC 32 \\
\hline AR44 & $\begin{array}{l}\text { P M TR P II COS II } \\
\text { P P }\end{array}$ & $\begin{array}{l}\text { Emperor, stg 1, holding } \\
\text { globe and spear }\end{array}$ & Septimius Severus RIC 50 \\
\hline AR45 & $\begin{array}{l}\text { P M TR P II COS II } \\
\text { P P }\end{array}$ & $\begin{array}{l}\text { Sol, stg } 1 \text {, raising } r \text { hand and } \\
\text { holding whip }\end{array}$ & Elagabalus $R I C 17$ \\
\hline AR46 & $\begin{array}{l}\text { P M TR P III COS II } \\
\text { P P }\end{array}$ & $\begin{array}{l}\text { Minerva, stg } 1 \text {, holding spear } \\
\text { and round shield }\end{array}$ & Septimius Severus RIC 53 \\
\hline AR47 & $\begin{array}{l}\text { P M TR P III COS II } \\
\text { P P }\end{array}$ & $\begin{array}{l}\text { Fortuna, stg } 1 \text {, holding } \\
\text { rudder on globe and } \\
\text { cornucopiae }\end{array}$ & Septimius Severus RIC 69 et al. \\
\hline AR48 & $\begin{array}{l}\text { P M TR P III COS III } \\
\text { P P }\end{array}$ & $\begin{array}{l}\text { Sol, radiate, walking } 1 \text {, } \\
\text { raising } \mathrm{r} \text { hand and holding } \\
\text { whip; star in field }\end{array}$ & Elagabalus $R I C 28$ \\
\hline AR49 & $\begin{array}{l}\text { P M TR P IIII COS } \\
\text { III P P }\end{array}$ & $\begin{array}{l}\text { Sol, adv 1, raising } \mathrm{r} \text { hand and } \\
\text { holding whip; star in field }\end{array}$ & Elagabalus $R I C$ 40-1 \\
\hline AR50 & $\begin{array}{l}\text { P M TR P IIII COS } \\
\text { III P P }\end{array}$ & $\begin{array}{l}\text { Providentia, stg } 1 \text {, holding a } \\
\text { rod over globe at feet and } \\
\text { with cornucopiae in } 1 \text {; star in } \\
1 \text { field }\end{array}$ & Elagabalus $R I C 42-3$ \\
\hline AR51 & $\begin{array}{l}\text { P M TR P IIII COS } \\
\text { III P P }\end{array}$ & $\begin{array}{l}\text { Emperor, stg 1, sacrificing } \\
\text { with dish over altar and } \\
\text { holding club or branch in 1; } \\
\text { star in } 1 \text { field }\end{array}$ & Elagabalus $R I C 177$ \\
\hline AR52 & $\begin{array}{l}\text { P M TR P V COS II } \\
\text { P P }\end{array}$ & $\begin{array}{l}\text { Genius, stg } 1 \text {, sacrificing out } \\
\text { of patera over altar, holding } \\
\text { corn-ears }\end{array}$ & $\begin{array}{l}\text { Septimius Severus RIC } 87 \\
\text { Severus Alexander RIC } 55\end{array}$ \\
\hline AR53 & $\begin{array}{l}\text { P M TR P V COS II } \\
\text { P P }\end{array}$ & $\begin{array}{l}\text { Fortuna, stg } 1 \text {, holding } \\
\text { rudder and cornucopiae }\end{array}$ & $\begin{array}{l}\text { Septimius Severus RIC } 104 \text { or } \\
115 \mathrm{~A}\end{array}$ \\
\hline AR54 & $\begin{array}{l}\text { P M TR P VI COS II } \\
\text { P P }\end{array}$ & $\begin{array}{l}\text { Annona, stg } 1 \text {, holding corn- } \\
\text { ears and cornucopiae; } \\
\text { modius at feet }\end{array}$ & Severus Alexander RIC 65 \\
\hline AR55 & $\begin{array}{l}\text { P M TR P VI COS II } \\
\text { P P }\end{array}$ & $\begin{array}{l}\text { Emperor sacrificing out of } \\
\text { dish over lighted altar }\end{array}$ & Severus Alexander RIC 70 \\
\hline AR56 & $\begin{array}{l}\text { P M TR P VIIII COS } \\
\text { III P P }\end{array}$ & $\begin{array}{l}\text { Sol, stg } r \text {, head turned } 1 \text {, } \\
\text { raising } r \text { hand and holding } \\
\text { globe }\end{array}$ & Severus Alexander RIC 102 \\
\hline AR57 & $\begin{array}{l}\text { P M TR P XVI COS } \\
\text { IIII P P }\end{array}$ & $\begin{array}{l}\text { Libertas, stg } 1 \text {, holding pileus } \\
\text { and rod }\end{array}$ & Caracalla $R I C 209 \mathrm{a}$ or $\mathrm{d}$ \\
\hline AR58 & $\begin{array}{l}\text { PART] MAX PONT } \\
\text { TR P IIII }\end{array}$ & $\begin{array}{l}\text { Two captives sitting below a } \\
\text { trophy }\end{array}$ & Septimius Severus RIC 90 or 321 \\
\hline AR59 & $\begin{array}{l}\text { PART] MAX TR P X } \\
\text { COS III P P }\end{array}$ & $\begin{array}{l}\text { Two captives sitting below a } \\
\text { trophy }\end{array}$ & Septimius Severus $R I C 185$ \\
\hline AR60 & $\begin{array}{l}\text { PONTIF TR P X } \\
\text { COS II }\end{array}$ & $\begin{array}{l}\text { Caracalla in military dress, } \\
\text { stg } \mathrm{r}, 1 \text { foot on helmet, } \\
\text { holding spear and } \\
\text { parazonium }\end{array}$ & Caracalla $R I C 95$ \\
\hline AR61 & Illegible & $\begin{array}{l}\text { Draped figure, stg } 1 \text {, holding } \\
\text { ?sceptre }\end{array}$ & \\
\hline
\end{tabular}




\begin{tabular}{|c|c|}
\hline $\begin{array}{l}\text { AE1 } \\
\text { AE2 }\end{array}$ & $\begin{array}{l}\text { Aes (AE) reverse lege } \\
\text { Uncertain } \\
\text { S/C }\end{array}$ \\
\hline AE3 & $\begin{array}{l}\text { AEQVITAS AVGG } \\
\text { S/C }\end{array}$ \\
\hline AE4 & $\begin{array}{l}\text { COL IVL AVG } \\
\text { PELLA }\end{array}$ \\
\hline AE5 & $\begin{array}{l}\text { CONCORDIA } \\
\text { AVGG } \\
\text { SC in ex. }\end{array}$ \\
\hline AE6 & $\begin{array}{l}\text { FELICITAS AVG } \\
\mathrm{S} / \mathrm{C}\end{array}$ \\
\hline AE7 & $\begin{array}{l}\text { FELICITAS TEMP.. } \\
\text { S/C }\end{array}$ \\
\hline AE8 & $\begin{array}{l}\text { LAETITIA AVG N } \\
\text { S/C }\end{array}$ \\
\hline AE9 & $\begin{array}{l}\text { LIBERALITAS } \\
\text { AVG } \\
\text { S/C }\end{array}$ \\
\hline AE10 & $\begin{array}{l}\text { MILIARIVM } \\
\text { SAECVLVM } \\
\text { S/C }\end{array}$ \\
\hline AE11 & $\begin{array}{l}\text { PAX AETERNA } \\
\text { S/C }\end{array}$ \\
\hline AE12 & $\begin{array}{l}\text { PAX AVGG } \\
\text { S/C }\end{array}$ \\
\hline AE13 & $\begin{array}{l}\text { PAX AUGVSTI } \\
\text { S/C }\end{array}$ \\
\hline AE14 & $\begin{array}{l}\text { PIETAS AVGG } \\
\text { S/C }\end{array}$ \\
\hline AE15 & $\begin{array}{l}\text { PVDICITIA AVG } \\
\text { SC in ex. }\end{array}$ \\
\hline AE16 & Uncertain \\
\hline
\end{tabular}

\section{RIC coin description}

SC within wreath

Diana, stg 1, holding out arrow and resting 1 hand on bow

\section{Aequitas, stg 1, holding scales and cornucopiae Pan, naked, seated 1 on rock, holding pedum; pan- pipes to 1 . \\ Concordia, seated 1 , holding patera and double cornucopiae}

Felicitas, stg 1, holding long caduceus and cornucopiae Felicitas, stg 1, holding long caduceus and cornucopiae Laetitia, stg 1, holding wreath and anchor Liberalitas, stg 1, holding abacus and cornucopiae

Low column

Pax, stg 1, holding branch and transverse sceptre

Pax holding branch and sceptre Pax, stg, head 1, holding branch and transverse sceptre

Pietas, veiled, stg 1, raising both hands

Pudicitia veiled, seated 1 , with $r$ hand drawing a veil and holding a sceptre in 1 Blank but with circular impression
Possible $R I C$ reference number Trajan RIC $646-50$ or 659

Faustina II RIC 1405

Trebonianus Gallus RIC 101

Possible Macedonian mint of Pella cf. $B M C$ Macedonia, Gordian III, RIC 44

Otacilia Severa RIC 203

Herennia Etruscilla RIC 133

Trebonianus Gallus RIC 105 or 106

Gordian III RIC 310

Philip I RIC 169

Gordian III RIC 328

Philip I RIC 169

Gordian III RIC 300

Philip I RIC 177

Trajan Decius RIC 120

Otacilia Severa RIC 199

Gordian III RIC 319c

Philip I RIC 184b

Severus Alexander RIC 165

Trebonianus Gallus RIC 115

Maximinus RIC 58-60

Gordian III RIC 256

Trajan Decius RIC 125

Trebonianus Gallus RIC

116 or 117

Otacilia Severa RIC 209

Herennia Etruscilla RIC 136

\section{APPENDIX 2. OBVERSE LEGENDS AND REVERSE TYPES OF THE LONDON WALL MOULDS}

The obverse legends for each emperor or empress recorded from the moulds are listed below with an indication of the reverse types (as listed in Appendix 1). Under each emperor, the reverse types are listed numerically with a mould total for the type of coin being copied, differentiated between silver coinage (AR) and aes coinage (AE). The moulds are recorded as complete or incomplete (complete, 90 per cent and larger, are recorded first; incomplete, less than 90 per cent and more fragmentary, recorded second within the brackets). Uncertain reverses have been included where specific features could be recorded, but the reverse type could not be identified with any certainty. 
1: Trajan (26 moulds)

Obv:

...TRAIANO OPTIMO...

2: Antoninus Pius (7 moulds)

Obv:

...AVG PIVS

mostly illegible legend

3: Faustina I (1 mould)

Obv:

DIVA FAVSTINA

4: Faustina II (8 moulds)

Obv:

FAVSTINA AVG PII AVG FIL

5: Septimius Severus (54 moulds)

Obvs:

IMP PERT. . .AVG COS II

IMP CAES ...PERT AVG COS II

L SEPT SEV PERT AVG IMP VII

L SEPT SEV PERT AVG IMP VIII

L SEPT SEV PERT AVG IMP XI

SEVERVS PIVS AVG
AE2: $4(2 ; 2)$

AE4: $1(0 ; 1)$

AE5: $1(0 ; 1)$

AE9: $1(1 ; 0)$

AE10: $3(0 ; 3)$

AE5: $1(0 ; 1)$

AE8: $1(0 ; 1)$

AE13: $2(1 ; 1)$

AR40: $1(1 ; 0)$

AE Obv only: $2(1 ; 1)$

AE6: $1(0 ; 1)$

AE8: $3(1 ; 2)$

AR Obv only: $4(0 ; 4)$

AR2: $1(0 ; 1)$

AR6: $1(0 ; 1)$

AR9: $1(0 ; 1)$

AR10: $3(1 ; 2)$

AR14: $1(1 ; 0)$

AR18: $1(0 ; 1)$

AR19: $2(0 ; 2)$

AR21: $1(0 ; 1)$

AR22: $2(0 ; 2)$

AR25: $1(0 ; 1)$

AR31: $5(1 ; 4)$

AR32: $5(1 ; 4)$

AR33: $1(0 ; 1)$

6: Julia Domna (50 moulds)

Obvs:

IVLIA AVGVSTA

IVLIA DOMNA AVG

IVLIA PIA FELIX AVG
AR Obv only: $1(0 ; 1)$

AR16: $3(0 ; 3)$

AR18: $1(0 ; 1)$

AR19: $4(1 ; 3)$

AR20: $1(0 ; 1)$

AR21: $2(2 ; 0)$

AR25: $1(0 ; 1)$

AR28: $1(0 ; 1)$

AR31: $1(0 ; 1)$

AR32: $1(0 ; 1)$

AR33: $2(0 ; 2)$

AR36: $3(0 ; 3)$

AR37: $1(0 ; 1)$

AR39: $3(1 ; 2)$
AE13: $2(0 ; 2)$

AE14: $2(2 ; 0)$

AE15: $3(0 ; 3)$

AE Uncertain: $9(0 ; 9)$

AE15: $2(0 ; 2)$

AE Uncertain: $1(0 ; 1)$
AE13: $1(1 ; 0)$

AE Uncertain: $1(0 ; 1)$
AR36: $1(0 ; 1)$

AR39: $1(0 ; 1)$

AR40: $3(1 ; 2)$

AR41: $1(0 ; 1)$

AR46: $1(1 ; 0)$

AR47: $1(1 ; 0)$

AR54: $4(0 ; 4)$

AR55: $3(0 ; 3)$

AR57: $1(0 ; 1)$

AR58: $1(0 ; 1)$

AR59: $1(0 ; 1)$

AR60: $4(3 ; 1)$

AR Uncertain: $3(0 ; 3)$ 
7: Geta (4 moulds)

Obv:

P SEPT GETA CAES PONT

8: Caracalla (27 moulds)

Obvs:

ANTONINVS PIVS AVG

ANTONINVS PIVS AVG BRIT

IMP C M AVR ANTONINVS PONT AVG
AR Obv only: $1(0 ; 1)$

AR9: $1(0 ; 1)$

AR Obv only: $1(0 ; 1)$

AR9: $2(1 ; 1)$

AR20: $1(0 ; 1)$

AR25: $3(2 ; 1)$

AR26: $1(0 ; 1)$

AR30: $1(0 ; 1)$

AR32: $2(1 ; 1)$

AR33: $1(1 ; 0)$

AR Obv only: $1(0 ; 1)$

AR21: $1(1 ; 0)$

AR Obv only: $7(1 ; 6)$

AR3: $2(1 ; 1)$

AR6: $2(1 ; 1)$

AR7: $1(1 ; 0)$

AR9: $5(1 ; 4)$

AR12: $1(1 ; 0)$

AR13: $1(0 ; 1)$

AR15: $1(0 ; 1)$

AR16: $6(1 ; 5)$

AR17: $2(1 ; 1)$

AR18: $3(1 ; 2)$

AR20: $2(0 ; 2)$

AR21: $5(1 ; 4)$

AR22: $2(0 ; 2)$

AR23: $1(0 ; 1)$

AR25: $2(0 ; 2)$

AR27: $1(0 ; 1)$

AR28: $1(0 ; 1)$

AR29: $2(0 ; 2)$

AR32: $1(1 ; 0)$

AR Obv only: $1(1 ; 0)$

AR6: $2(1 ; 1)$

AR11: $1(0 ; 1)$

AR18: $1(0 ; 1)$

AR19: $1(1 ; 0)$

AR20: $2(0 ; 2)$

AR22: $1(0 ; 1)$

AR28: $4(2 ; 2)$

AR28/29: $1(0 ; 1)$
AR25: $1(0 ; 1)$

AR42: $1(0 ; 1)$

AR34: $1(0 ; 1)$

AR35: $1(0 ; 1)$

AR36: $1(0 ; 1)$

AR37/38: $1(1 ; 0)$

AR48: $2(0 ; 2)$

AR54: $1(1 ; 0)$

AR61: $1(1 ; 0)$

AR Uncertain: $7(0 ; 7)$

AR50: $1(1 ; 0)$

AR60: $1(1 ; 0)$

AR33: $6(1 ; 5)$

AR36: $3(1 ; 2)$

AR37: $1(0 ; 1)$

AR39: $3(0 ; 3)$

AR40: $2(1 ; 1)$

AR41: $1(0 ; 1)$

AR42: $3(2 ; 1)$

AR43: $2(1 ; 1)$

AR46: $2(2 ; 0)$

AR48: $3(1 ; 2)$

AR50: $1(0 ; 1)$

AR52: $1(0 ; 1)$

AR53: $1(1 ; 0)$

AR54: $1(1 ; 0)$

AR55: $2(0 ; 2)$

AR57: $3(0 ; 3)$

AR58: $1(0 ; 1)$

AR60: $1(0 ; 1)$

AR61: $2(0 ; 2)$

AR Uncertain: $7(0 ; 7)$

AR33: $1(1 ; 0)$

AR39: $1(0 ; 1)$

AR46: $1(1 ; 0)$

AR49: $1(0 ; 1)$

AR50: $1(0 ; 1)$

AR52: $1(1 ; 0)$

AR59: $2(0 ; 2)$

AR Uncertain: $3(0 ; 3)$ 
11: Julia Soaemias (3 moulds)

Obv:

IVLIA SOAEMIAS AVG

12: Julia Paula (7 moulds)

Obv:

AR51: $1(0 ; 1)$

AR18: $1(1 ; 0)$

AR19: $1(0 ; 1)$

AR23: $1(1 ; 0)$

AR29: $1(1 ; 0)$

AR30: $1(0 ; 1)$

AR49: $1(1 ; 0)$

AR Uncertain: $1(1 ; 0)$

13: Severus Alexander ( 87 moulds: $84 \mathrm{AR}$ and $3 \mathrm{AE}$ )

Obvs:

IMP SEV ALEXAND AVG

IMP C M AVR SEV ALEXAND AVG

IMP ALEXANDER AVG

AR Obv only: $7(4 ; 3)$

AR3: $1(0 ; 1)$

AR4: $3(1 ; 2)$

AR6: $3(2 ; 1)$

AR7: $3(0 ; 3)$

AR8: $1(1 ; 0)$

AR10: $3(0 ; 3)$

AR11: $1(0 ; 1)$

AR12: $2(1 ; 1)$

AR13: $2(1 ; 1)$

AR14: $1(0 ; 1)$

AR15: $2(0 ; 2)$

AR18: $3(1 ; 2)$

AR19: $1(0 ; 1)$

AR20: $2(1 ; 1)$

AR21: $3(1 ; 2)$

AR22: $1(1 ; 0)$

AR25: $3(0 ; 3)$

14: Julia Mamaea (59 moulds)
Obv:

IVLIA MAMAEA AVG

AR Obv only: $3(1 ; 2)$

AR3: $1(0 ; 1)$

AR6: $4(2 ; 2)$

AR8: $1(1 ; 0)$

AR9: $1(0 ; 1)$

AR10: $2(1 ; 1)$

AR12: $3(1 ; 2)$

AR13: $2(0 ; 2)$

AR14: $1(0 ; 1)$

AR15: $2(1 ; 1)$

AR16: $1(0 ; 1)$

AR17: $1(0 ; 1)$

AR19: $1(1 ; 0)$

AR23: $1(0 ; 1)$

AR29: $1(0 ; 1)$

AR30: $1(0 ; 1)$

AR31: $2(0 ; 2)$

15: Orbiana (4 moulds)

Obv:

SALL BARBIA ORBIANA AVG
AR3: $1(0 ; 1)$

AR29: $1(1 ; 0)$
AR28/9: $1(0 ; 1)$

AR31: $5(2 ; 3)$

AE34: $2(0 ; 2)$

AR35: $1(0 ; 1)$

AR36: $3(0 ; 3)$

AR39: $2(1 ; 1)$

AR40: $1(0 ; 1)$

AR42: $2(0 ; 2)$

AR46: $1(0 ; 1)$

AR48: $5(2 ; 3)$

AR50: $3(1 ; 2)$

AR51: $4(1 ; 3)$

AR54: $1(0 ; 1)$

AR57: $2(1 ; 1)$

AR60: $2(0 ; 2)$

AR Uncertain: $7(1 ; 6)$

AE Obv only: $1(0 ; 1)$

AE Uncertain: $2(1 ; 1)$

AR32: $1(0 ; 1)$

AR35: $1(0 ; 1)$

AR36: $1(0 ; 1)$

AR37/8: $3(0 ; 3)$

AR40: $5(1 ; 4)$

AR41: $1(0 ; 1)$

AR42: $3(1 ; 2)$

AR43: $2(0 ; 2)$

AR47/53: $2(0 ; 2)$

AR50: $1(1 ; 0)$

AR51: $1(0 ; 1)$

AR52: $1(1 ; 0)$

AR54: $1(0 ; 1)$

AR56: $1(1 ; 0)$

AR60: $1(0 ; 1)$

AR Uncertain: $6(0 ; 6)$

AR33: $1(0 ; 1)$

AR Uncertain: $1(0 ; 1)$ 
16: Maximinus (33 moulds: $8 \mathrm{AR}$ and $25 \mathrm{AE}$ ) AR Obv: IMP MAXIMINVS PIVS AVG AE Obv: MAXIMINVS PIVS AVG GERM

17: Balbinus (1 mould)

Obv:

IMP C D CAEL BALBINVS AVG

18: Gordian III (17 moulds: $1 \mathrm{AR}$ and $16 \mathrm{AE})$ Obv:

IMP GORDIANVS PIVS FEL AVG

19: Philip I (39 moulds)

Obv:

IMP M IVL PHILIPPVS AVG

20: Otacilia Severa (55 moulds)

Obv:

MARCIA OTACIL SEVERA AVG

21: Trajan Decius (30 moulds)

Obv:

IMP C M Q TRAIANVS DECIVS

AVG

22: Herennia Etruscilla (66 moulds)

Obv:

HERENNIA ETRVSCILLA
AR30: $1(0 ; 1)$

AR35: $1(1 ; 0)$

AR44: $1(1 ; 0)$

AR48: $1(1 ; 0)$

AR Uncertain: $4(0 ; 4)$

AR36: $1(0 ; 1)$

AR16: $1(1 ; 0)$

AE Obv only: $6(0 ; 6)$

AE2: $1(0 ; 1)$

AE3: $1(1 ; 0)$

AE5: $3(0 ; 3)$

AE8: $6(2 ; 4)$

AE Obv only: $10(3 ; 7)$

AE2: $2(0 ; 2)$

AE3: $2(1 ; 1)$

AE5: $2(0 ; 2)$

AE6/7: $1(0 ; 1)$

AE9: $9(0 ; 9)$

AE Obv only: $2(0 ; 2)$

AE1: $1(0 ; 1)$

AE2: $2(0 ; 2)$

AE3: $3(1 ; 2)$

AE5: $2(0 ; 2)$

AE Obv only: $22(13 ; 9)$

AE2: $2(0 ; 2)$

AE5: $2(0 ; 2)$

AE6/7: $2(1 ; 1)$
AE Obv only: $2(0 ; 2)$

AE2: $1(0 ; 1)$

AE3: $1(0 ; 1)$

AE4: $1(0 ; 1)$

AE5: $2(1 ; 1)$

AE7: $2(0 ; 2)$

AE8: $1(0 ; 1)$

AE9: $5(0 ; 5)$

AE13: $1(0 ; 1)$

AE14: $1(0 ; 1)$

AE15: $1(0 ; 1)$

AE Uncertain: $7(0 ; 7)$

AE2: $2(0 ; 2)$

AE8: $2(0 ; 2)$

AE9: $2(0 ; 2)$

AE10: $2(1 ; 1)$

AE11: $1(1 ; 0)$

AE14: $3(0 ; 3)$

AE15: $1(0 ; 1)$

AE Uncertain: $3(0 ; 3)$

AE10: $4(3 ; 1)$

AE13: $7(3 ; 4)$

AE15: $7(2 ; 5)$

AE Uncertain: $4(0 ; 4)$

AE10: $1(0 ; 1)$

AE13: $5(0 ; 5)$

AE14: $3(0 ; 3)$

AE15: $6(1 ; 5)$

AE Uncertain: $14(2 ; 12)$

AE8: $1(0 ; 1)$

AE10: $2(0 ; 2)$

AE15: $5(1 ; 4)$

AE Uncertain: $12(0 ; 12)$

AE11: $1(0 ; 1)$

AE13: $4(0 ; 4)$

AE14: $1(0 ; 1)$

AE15: $3(0 ; 3)$ 
AE8: $1(0 ; 1)$

AE10: $3(1 ; 2)$

AE3: $3(0 ; 3)$

AE5: $1(1 ; 0)$

AE6/7: $1(0 ; 1)$
AE16: $14(0 ; 14)$

AE Uncertain: $11(1 ; 10)$

AE10: $1(0 ; 1)$

AE16: $2(0 ; 2)$

AE Uncertain: $2(0 ; 2)$

AR and AE Reverses only (101 moulds: 49 AR and 52 AE)
AR1: $1(1 ; 0)$
AR2: $1(1 ; 0)$
AR4: $1(0 ; 1)$
AR5: $2(1 ; 1)$
AR7: $1(1 ; 0)$
AR8: $1(1 ; 0)$
AR9: $2(1 ; 1)$
AR10/11: $1(0 ; 1)$
AR14: $1(1 ; 0)$
AR16: $1(1 ; 0)$
AR18: $1(0 ; 1)$
AR20: $1(0 ; 1)$
AR24: $1(1 ; 0)$
AR30: $2(2 ; 0)$
AR31: $1(0 ; 1)$

AR32: $1(0 ; 1)$

AR36: $1(1 ; 0)$

AR39: $3(1 ; 2)$

AR42: $1(0 ; 1)$

AR43: $2(2 ; 0)$

AR46: $2(1 ; 1)$

AR47: $1(1 ; 0)$

AR48: $3(1 ; 2)$

AR52: $1(1 ; 0)$

AR57: $1(0 ; 1)$

AR58: $1(0 ; 1)$

AR60: $1(1 ; 0)$

AR61: $2(1 ; 1)$

\author{
AE5: $2(0 ; 2)$ \\ AE6: $1(0 ; 1)$ \\ AE9: $9(3 ; 6)$ \\ AE10: $1(0 ; 1)$ \\ AE12: $1(1 ; 0)$ \\ AE13: $1(1 ; 0)$ \\ AE15: $19(5 ; 14)$ \\ AE16: $1(1 ; 0)$ \\ AE Uncertain: $17(0 ; 17)$
}

\section{APPENDIX 3. RELEVANT COINS FROM 85 LONDON WALL (BLM87)}

BLM87[219]

Copper-alloy 'silver' denarius, found amongst the moulds Diam: $19 \mathrm{~mm}$ Less than $1 \mathrm{~mm}$ thick (FIG. 6b)

BLM87[0]<13> Copper-alloy hybrid coin from elsewhere on the site

Diam: $24 \mathrm{~mm}$

Thick: $2 \mathrm{~mm}$

(FIG. 6a)
Obv: IMP C M AVR SEV

ALEXAND AVG

Laureate head $r$

Rev: P M TR P VI COS II P P

Annona, stg 1, holding corn-ears and cornucopiae; modius at feet Mould reverse type AR54

Ref: RIC Severus Alexander, 65

Obv: [IMP] M IVL PHILIPPVS

AVG

Laureate head $r$

Rev: FELICITAS [AVG]

Felicitas, stg 1, holding long

caduceus and cornucopiae

Mould reverse type AE6

Reverse ref: RIC Gordian III, 310
Some surface corrosion.

It has a seam-line along its edge, clearly showing that it was cast.

A specific area on the edge of the coin shows the 'casting-cup' location where the metal had flowed into the mould.

This would have been left attached until the metal had cooled and hardened and was then cut off leaving the edge flat at that point.

Modern break, in 2 pieces.

Some surface corrosion.

It was made of a copper alloy that contained small traces of lead. The cast coin has a seam around its edge, which showed that it came from two moulds: one with a deep impression; the other, less so. This may have been intentional since it would have left a seam-line close to the top edge, thus making it less detectable as a forgery. 


\section{SUPPLEMENTARY MATERIAL}

For supplementary material (ONLINE TABLES 1-2) for this article please visit http://journals. cambridge.org/bri

\section{ACKNOWLEDGEMENTS}

My grateful thanks go to the City of London Archaeological Trust for a generous grant towards this paper. Thanks also go to Andrew Burnett, for both commenting on a draft of this paper and for his advice when the moulds were first excavated, and more recently to Richard Abdy and Amelia Dowler, of the Coins and Medals Department, and Roger Bland, all of the British Museum. I must also thank Dana Goodburn-Brown, whose investigative scientific research on the moulds first began in 1988, and Nick Griffiths for his illustrations; Dave Sankey and Fiona Seeley at Museum of London Archaeology for their assistance in site matters and the identification of the clay; Mike Heyworth formerly of the Ancient Monuments Laboratory for the analyses and Vicki Ridgeway of Pre-Construct Archaeology for allowing me access to the Bermondsey Square examples. I would also like to thank various departments of the Museum of London: the staff of the Department of Archaeological Collections and Archive for their assistance, and students and conservators in the Conservation and Collections Care Department for the invaluable silicone casts which facilitated the identification of some of the moulds. Mme Jacqueline Lallemand (Belgium) and Jérémie Chameroy (Frankfurt) kindly provided me with information about their respective research.

Jenny Hall, London

jenny.m.hall@hotmail.com

\section{BIBLIOGRAPHY}

Abdy, R.A. 2003: 'Worn sestertii in Roman Britain and the Longhorsley hoard', Numismatic Chronicle 163, $137-46$

Abdy, R.A. 2007: 'The decline and fall of the sestertius in Roman Britain: a case study', in I Ritrovamenti monetali e la legge di Gresham: Atti del III Congresso internazionale di numismatica e di storia monetaria, Padova, 28-29 ottobre 2005, Padua, 45-55

Abdy, R.A. forthcoming: 'Nevill Holt, Leicester', in Coin Hoards from Roman Britain

Alfoldi, M.-R. 1974: 'Die Fälscherformen von Pachten', Germania 52, 426-47

Besly, E., and Bland, R. 1983: The Cunetio Treasure: Roman Coinage of the Third Century AD, London

Boon, G.C. 1988: 'Counterfeit coins in Roman Britain', in J. Casey and R. Reece (eds), Coins and the Archaeologist (2nd edn), London, 102-88

Boon, G.C., and Rahtz, P.A. 1965: 'Third-century counterfeiting at Whitchurch, Somerset', Archaeological Journal 122, 13-51

Brickstock, R.J., and Casey, P.J. 2009: 'The coins', in A. Rushworth, Housesteads Roman Fort, the Grandest Station: Excavation and Survey at Housesteads, 1954-95, English Heritage Archaeological Report, Swindon, 363-77

Douglas, A., and Haslam, A. forthcoming: Excavations at Bermondsey Square, Abbey Street and Stevens Street, London Borough of Southwark, London SE1, London

Goodburn-Brown, D. 1998: 'Surface values: coins under the microscope', in D. Goodburn-Brown and J. Jones (eds), Look after the Pennies: Conservation and Numismatics in the 1990s, London, 19-24

Hall, J. 1986: 'A hoard from Billingsgate, London', in A.M. Burnett and R.F. Bland (eds), Coin Hoards from Roman Britain, Volume VI, British Museum Occasional Paper 58, London, 57-8

Hall, J. 2005: 'The shopkeepers and craft-workers of Roman London', in A. MacMahon and J. Price (eds), Roman Working Lives and Urban Living, Oxford, 125-44

Lallemand, J. 1994: 'Les moules monétaires de Saint-Mard (Virton, Belgique) et les moules de monnaies', in A. Cahen-Delhaye et al., Un quartier artisanal de l'agglomération gallo-romaine de Saint-Mard (Virton), Études et Documents, Fouilles 1, Namur, 141-77 
Merrifield, R. 1983: London, City of the Romans, London

Pilon, F. 2011: "Could the unofficial mint called "Atelier II" be identified with the officinae of Châteaubleau (France)?', in N. Holmes (ed.), Proceedings of the XIVth International Numismatic Congress Glasgow 2009, Glasgow, 906-10

Raub, C., and Zwicker, U. 2012: 'Cast forgeries of Roman denarii and antoniniani, silver-tin-copper and copper-tin alloys', Numismatic Chronicle 172, 219-22

Reece, R. 2002: The Coinage of Roman Britain, Stroud

RIC: H. Mattingly, E.A. Sydenham et al., The Roman Imperial Coinage (1923-), London

Schofield, J., and Maloney, C. (eds) 1998: Archaeology in the City of London 1907-91: A Guide to Records of Excavations by the Museum of London, The Archaeological Gazetteer Series 1, London

Seeley, F., and Drummond-Murray, J. (eds) 2005: Roman Pottery Production in the Walbrook Valley, Excavations at 20-28 Moorgate, City of London, 1998-2000, MoLAS Monograph 25, London

Speidel, M. 1992: 'Roman army pay scales', Journal of Roman Studies 82, 87-106

Sutherland, C.H.V. 1937: Coinage and Currency in Roman Britain, London

Walton, P. 2012: Rethinking Roman Britain: Coinage and Archaeology, Collection Moneta 137, Wetteren

Wheeler, R.E.M., and Wheeler, T.V. 1936: Verulamium: A Belgic and Two Roman Cities, Reports of the Research Committee of the Society of Antiquaries of London 11, Oxford

Zeepvat, R.J. 1994: 'A Roman coin manufacturing hoard from Magiovinium, Fenny Stratford, Bucks', Britannia 25, 1-19 